\title{
Syntheses of Dimethyl (1S,2R)-3-Bromocyclohexa-3,5-diene-1,2-dicarboxylate and its Enantiomer
}

\author{
Christian G. Blüchel, Jiri Mikusek, Anthony C. Willis, Michael G. Gardiner \\ and Martin G. Banwell*
}

Research School of Chemistry, Institute of Advanced Studies, The Australian National University, Canberra, ACT 2601, Australia

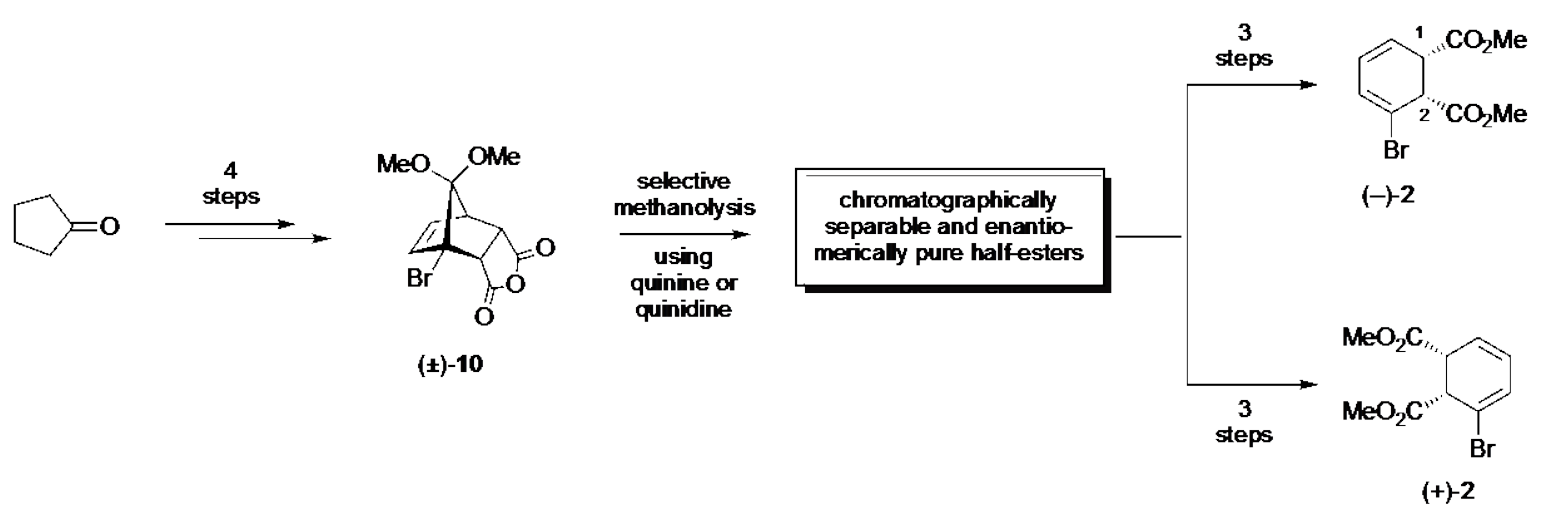

ABSTRACT: The title compounds, (-)-2 and (+)-2, representing potentially valuable building blocks for chemical synthesis, have each been prepared from cyclopentanone in eight steps. The pivotal one involves a resolution, through the quinine- or quinidine-promoted methanolysis of the cyclic anhydride $( \pm)-\mathbf{1 0}$, leading to chromatographically separable pairs of enantiomerically pure forms of regio-isomeric methyl half-esters.

\section{INTRODUCTION}

For some time we have been exploiting various enzymatically-derived (and enantiomerically pure) cis-1,2-dihydrocatechols, including compound 1 (Figure 1), as starting materials for the synthesis of a wide range of biologically active natural products. ${ }^{1,2}$ In seeking to extend this type of work we required access to the title compounds (-)-2 and (+)-2. An examination of the literature revealed that the non-brominated and, therefore, $\mathrm{C}_{2}$-symmetric counterpart of the target compounds is known and had been prepared through either the chemical or electrochemical reduction of phthalic acid followed by esterification of the ensuing mixture of cis- and trans-cyclohexa-3,5-diene-1,2-dicarboxylic acids. ${ }^{3,4}$ However, in all of these sequences the trans-isomer appears to predominate. On this basis, we sought to establish new and stereoselective means for preparing the racemic and previously unreported diene diester ( \pm )-2 and to then identify resolution techniques that provide the constituent enantiomers in pure form. Herein we detail the successful realization of these objectives. 

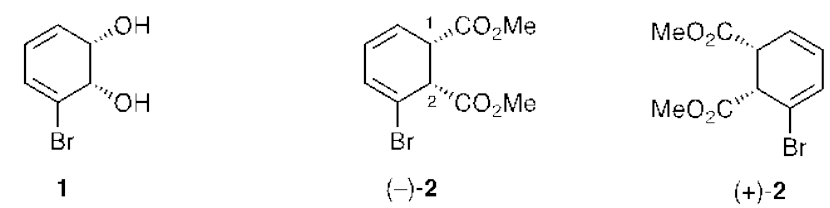

$(+)-2$

Figure 1: The enzymatically-derived cis-1,2-dihydrocatechol 1 and the targeted analogues (-)-2 and (+)-2

\section{RESULTS AND DISCUSSION}

\section{The Synthesis of Compound ( \pm )-2}

The synthetic sequence leading to the key bromocyclopentadiene required for accessing the initial target compound ( \pm )-2 started (Scheme 1) with the conversion of cyclopentanone (3) into the corresponding dimethyl ketal $4^{5}(62 \%)$ that was itself subjected to bromination and so forming the previously reported tribromide $( \pm)-5^{6}$ (58\%) together with small amounts of the chromatographically separable cis- and trans-2,5-dibromo-1,1-dimethoxycyclopentanes.

Scheme 1: Synthesis of the cyclopentadiene 6 and its participation in a Diels-Alder dimerization reaction.

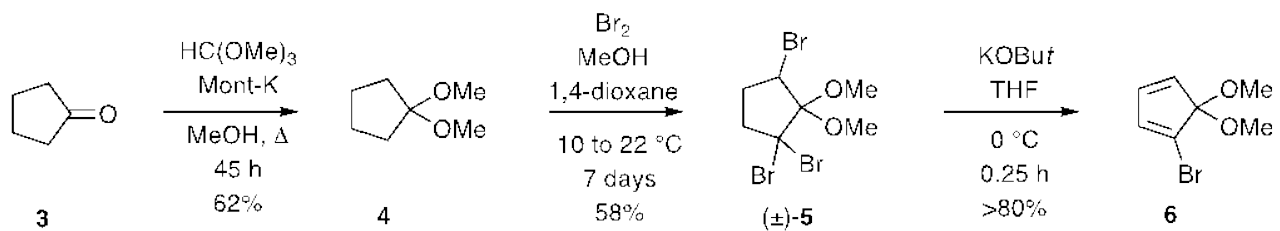

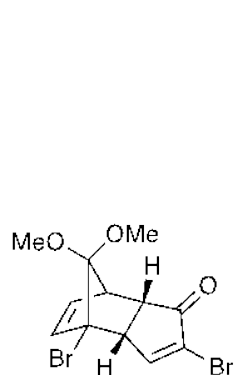

$( \pm)-8$

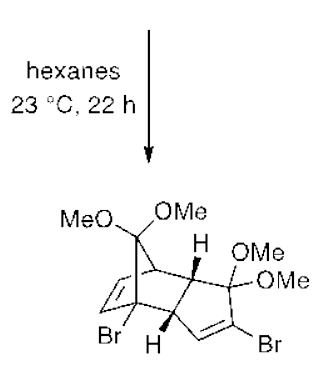

$( \pm)-7$

The structure of compound ( \pm )-5 was confirmed by single-crystal X-ray crystallography (see Experimental Section and Supporting Information - SI - for details). After extensive experimentation it was determined that the best means for effecting the two-fold dehydrobromination of tribromide $( \pm)$-5 involved its exposure to potassium tert-butoxide in THF at $0{ }^{\circ} \mathrm{C}$ for $0.25 \mathrm{~h}$. By such means, and after extractive work-up, a ca. $0.025 \mathrm{M}$ solution of diene $6^{6,7}(>80 \%)$ in hexane was obtained. On standing this rather reactive material was converted, via a Diels-Alder dimerization, into compound ( \pm )-7 (variable yields) that hydrolyzed on standing to 
give enone $( \pm)-\mathbf{8}^{8}$ (69\% from $\left.\mathbf{6}\right)$. The structures of both compounds $( \pm)-\mathbf{7}$ and $( \pm)-\mathbf{8}$ were also confirmed by single-crystal X-ray analysis (see Experimental Section and SI for details).

Despite its propensity to dimerize, diene 6 could be engaged in a Diels-Alder reaction, at $23{ }^{\circ} \mathrm{C}$, with maleic anhydride (9) (Scheme 2) and so affording the expected adduct ( \pm )-10 in 74\% yield and the structure of which was also confirmed by single-crystal X-ray analysis. Hydrolysis of the ketal residue associated with the last compound was best accomplished using aluminium trichloride in dichloromethane and after extractive work-up the anticipated ketone $( \pm)-\mathbf{1 1}$ was obtained in $68 \%$ yield and as a crystalline solid so the structure was again confirmed by singlecrystal X-ray analysis. On heating in refluxing o-xylene compound $( \pm)-\mathbf{1 1}$ engaged in chelotropic extrusion of carbon monoxide ${ }^{9}$ and thereby forming the anticipated diene $( \pm)-\mathbf{1 2}(78 \%)$ that could be purified by kugelrohr distillation although on prolonged exposure to high temperatures it underwent Diels-Alder dimerization to give compound ( \pm )-13 in varying yields.

Scheme 2: Elaboration of cyclopentadiene 6 to the cyclic anhydride $( \pm)-\mathbf{1 2}$

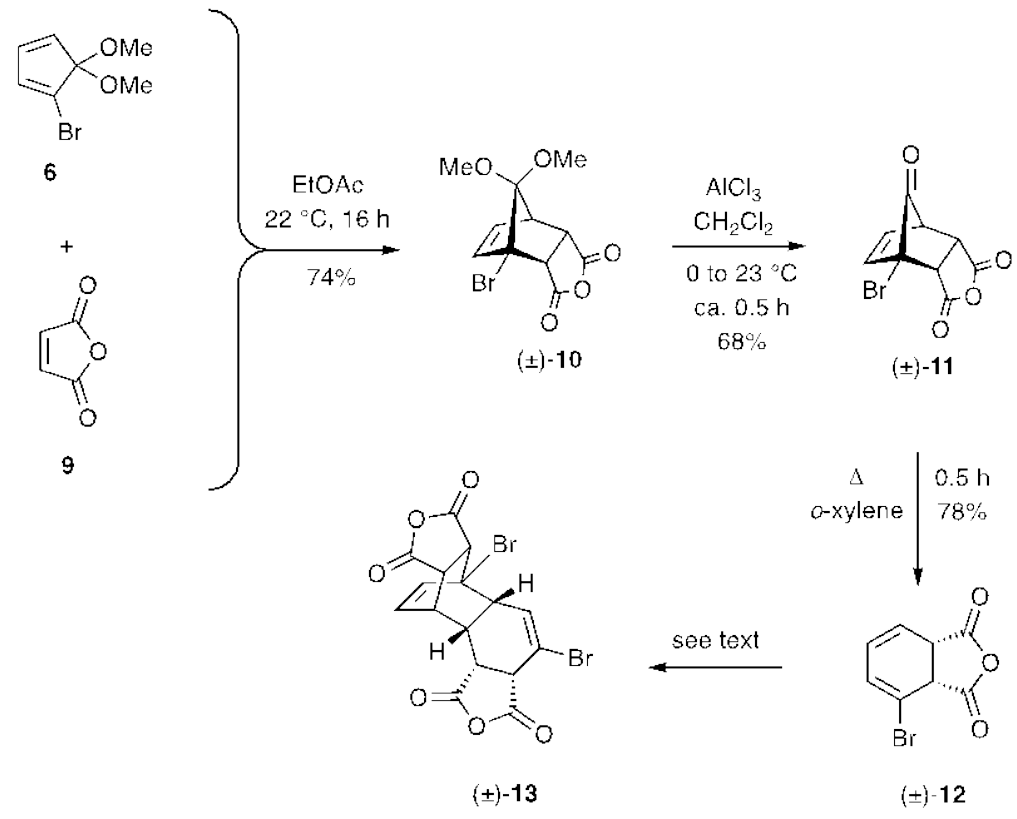

Various efforts were made to adapt the chemistry outlined in Scheme 2 to the preparation of the diester $( \pm)$-2. The ultimately successful route is shown Scheme 3 and was started by treating a methanolic solution of the Diels-Alder adduct $( \pm)-\mathbf{1 0}$ with catalytic amounts of sulfuric acid under reflux and so affording the di-ester $( \pm)-\mathbf{1 4}$ (93\%) that upon exposure to $\mathrm{AlCl}_{3}$ in dichloromethane followed by aqueous work-up gave the keto-diester $( \pm)-\mathbf{1 5}(84 \%)$, the structure 
of which was again confirmed by single-crystal X-ray analysis. Heating neat samples of compound $( \pm)-15$ at $220-230{ }^{\circ} \mathrm{C}$ under a nitrogen atmosphere until gas evolution ceased ( $\mathrm{ca} .5$ minutes) then afforded the target and previously unreported compound $( \pm)-2(75 \%)$, the spectral data for which were in complete accord with the illustrated structure. In particular, the infra-red spectrum of this compound showed a strong ester carbonyl stretching band at $1740 \mathrm{~cm}^{-1}$ while the ${ }^{13} \mathrm{C}\left\{{ }^{1} \mathrm{H}\right\}$ NMR spectrum displayed resonances at $\delta_{\mathrm{C}} 171.0$ and 169.6 arising from the associated $\mathrm{C}=\mathrm{O}$ carbons as well as two (at $\delta_{\mathrm{C}} 52.6$ and 52.5) due to the corresponding methoxy group carbons. In the ${ }^{1} \mathrm{H}$ NMR spectrum the signals due to the oxymethine protons appeared at $\delta_{\mathrm{H}} 3.82(\mathrm{td}, J=7.6$ and $2.8 \mathrm{~Hz})$ and $3.77(\mathrm{~d}, J=7.6 \mathrm{~Hz})$ and the magnitude of their mutual coupling suggests a cis-relationship between them and, therefore, the same relationship between the associated carbomethoxy groups. Small amounts of compounds $( \pm)-\mathbf{1 6}$ and 17 were often also formed during the thermolysis of ketone $( \pm)-\mathbf{1 5}$ but could be removed by flash chromatographic methods. These by-products arise through the epimerization and aromatization, respectively, of diester $( \pm)-2$.

Scheme 3: Conversion of anhydride $( \pm)-10$ into di-ester $( \pm)-2$

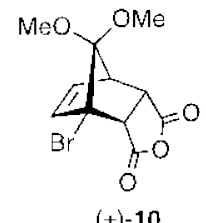

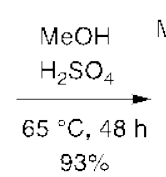

$93 \%$

$( \pm)-10$

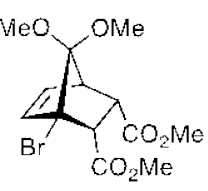

$( \pm)-14$

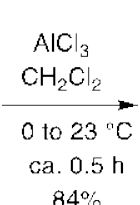

$84 \%$

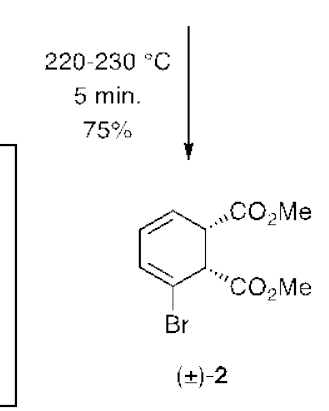

\section{Resolution Protocols Leading to Compounds (+)- and (-)-2}

Initial attempts to effect a resolution involved treating diester $( \pm)-\mathbf{1 4}$ with pig's liver esterase $(\mathrm{PLE})^{10}$ in a mixture of phosphate buffer and acetone $(5 \% \mathrm{v} / \mathrm{v})$ at $31-33{ }^{\circ} \mathrm{C}$ (Scheme 4$)$. After 48 h, at which point ca. $50 \%$ of the starting material had been consumed, the reaction mixture was subjected to work-up and the product half-ester $(+)-18$ (47\%), wherein the ester residue remote from the bridge-head bromine had been cleaved, was separated from the unreacted di-ester 
(34\%). The half-ester was treated with TMS-diazomethane at ambient temperatures and thereby affording the corresponding diester. Chiral HPLC analysis of the recovered diester established that this was obtained in $43 \%$ ee while its counterpart derived from the half-ester was enriched, to the extent of $46 \%$ ee, in the other enantiomer. Both of these diesters were semi-solids and upon fractional recrystallization the solid racemate $( \pm)-\mathbf{1 4}$ was removed from each sample and chiral HPLC analysis of the mother liquors established that compound (+)-14 had now been obtained in $\mathbf{8 3 \%}$ ee while enantiomer $(-)-\mathbf{1 4}$ now had an ee of $75 \%$. The assigned absolute configurations of the major enantiomeric forms of each of these partially resolved diesters follows from chemical correlation studies and a single-crystal X-ray analysis of an enantiomerically pure material as detailed below.

Scheme 4: The reaction of diester $( \pm)-14$ with PLE.

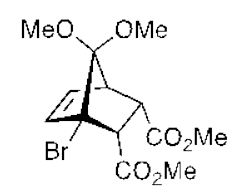

(士) -14

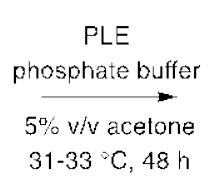

ca. $50 \%$

conversion

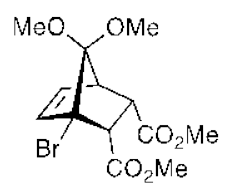

(+)-14

$34 \%, 43 \%$ ee

$(83 \%$ ee after recryst.)

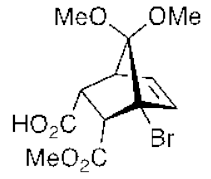

$(-)-18$
$47 \%$

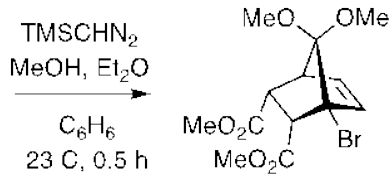

(-) -14

quant., $46 \%$ ee (75\% ee after recryst.)

The structure of half-ester (-)-18 follows from a single-crystal X-ray analysis of the associated racemate (obtained through fractional crystallization, from diethyl ether, of the partially enantiomerically enriched material) and the preferential formation of this compound is consistent with the outcomes of related PLE-mediated mono-cleavages of other di-esters. ${ }^{10}$

A more efficient method for the preparation of the title diesters, and now in essentially enantiomerically pure form, employed protocols developed by Bolm and co-workers. ${ }^{11,12}$ So, for example, dropwise addition, at $-55^{\circ} \mathrm{C}$, of methanol to a toluene/carbon tetrachloride solution of anhydride $( \pm)$-10 containing 1.1 mole equivalents of quinine afforded a regio-isomeric mixture of the two possible half-esters (Scheme 5) that could be separated from one another by reversephase HPLC. The ${ }^{1} \mathrm{H}$ and ${ }^{13} \mathrm{C}\left\{{ }^{1} \mathrm{H}\right\}$ NMR spectra derived from half-ester (+)-18 were identical, in all respects, with the compound obtained from the PLE-mediated hydrolysis of compound $( \pm)-\mathbf{1 4}$ while those derived from regio-isomer (-)-19 were distinctly different. Chiral HPLC analysis of the former product revealed it had been obtained in $84 \%$ ee and was of the opposite enantiomeric form to that generated in the PLE experiment. Fractional crystallization of this material from 
diethyl ether served to remove most of the crystalline racemate $( \pm)-\mathbf{1 8}$ and thereby producing $(+)-18$ in 96\% ee and as a clear, colorless oil. On the other hand, compound (-)-19 was obtained directly in $97 \%$ ee as a clear, colorless oil. The illustrated conversion could be carried out on ca. 8 gram scale and the quinine was recovered essentially quantitatively by simple extractive methods using mineral acid $(\mathrm{HCl})$.

Scheme 5: Quinine-promoted and enantioselective formation of half-esters (+)-18 and (-)-19 from anhydride $( \pm)-\mathbf{1 0}$
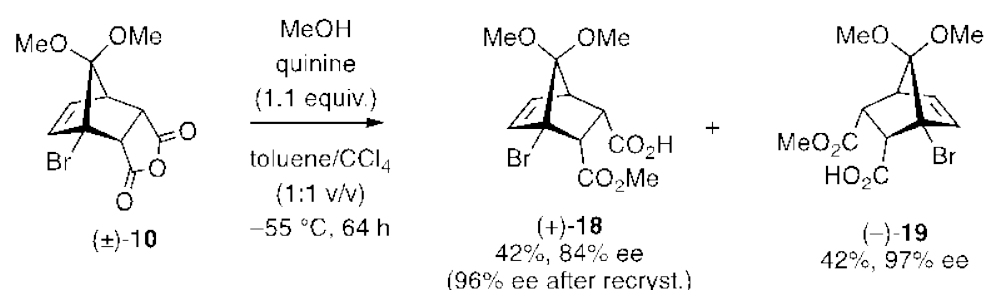

A complementary process for obtaining the enantiomeric half-esters $(-)-\mathbf{1 8}$ and $(+)-\mathbf{1 9}$ is shown in Scheme 6 and simply involved replacing quinine with its pseudo-enantiomer quinidine. Thus, reaction of anhydride $( \pm)$-10 with methanol at $-55{ }^{\circ} \mathrm{C}$ in the presence of quinidine afforded a chromatographically separable mixture of the half-esters (-)-18 (32\%) and (+)-19 (33\%), the first of these being obtained, as determined by chiral HPLC analysis, in 92\% ee and the second in $>99 \%$ ee. Fractional recrystallization the former product so as to remove the residual and crystalline racemate raised the ee of $(-)-\mathbf{1 8}$ to $98 \%$. Save for their optical rotations, the spectral data recorded on these half-esters matched those recorded for their enantiomers and, in the case of compound (-)-18, those of the corresponding racemate.

Scheme 6: The enantio-complementary formation of half-esters (-)-18 and (+)-19
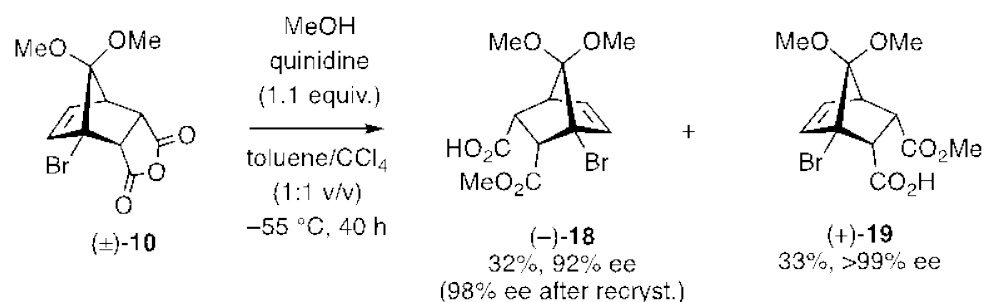

The simple synthetic sequence allowing for the elaboration of the laevorotatory pair of halfesters into the target diene diester $(+)-2$ is shown in Scheme 7 and involved the acid-catalyzed 
esterification of compound (-)-18 or (-)-19 with methanol and so affording the diester (-)-14 in 90-91\% yield. The more hindered acid (-)-19 reacted noticeably more slowly that its regioisomer. Treating compound (-)-14 with aluminium trichloride in dichloromethane at ambient temperatures for $0.33 \mathrm{~h}$ followed by an aqueous work-up gave the crystalline keto-diester (-)-15 in $84 \%$ yield and $>99 \%$ ee after recrystallization from diethyl ether. The structure, including absolute configuration, of compound (-)-15 was established by single crystal X-ray analysis and so confirming those of all the other compounds reported herein.

A variety of methods was examined in efforts to convert the keto diester into the target diene and the most effective conditions for this purpose involved microwave irradiation of a ca. $0.02 \mathrm{M}$ toluene solution of the substrate for $1 \mathrm{~h}$ at $300 \mathrm{~W}$ and during which the maximum temperature reached $170{ }^{\circ} \mathrm{C}$. By such means compound $(+)$-2 was obtained in $80 \%$ yield after flash chromatographic purification and without any significant contamination by compounds $\mathbf{1 6}$ and 17 (see Scheme 3) that were observed earlier when more conventional thermolytic conditions were employed.

Scheme 7: The elaboration of the laevorotatory pair of half-esters into compound (+)-2

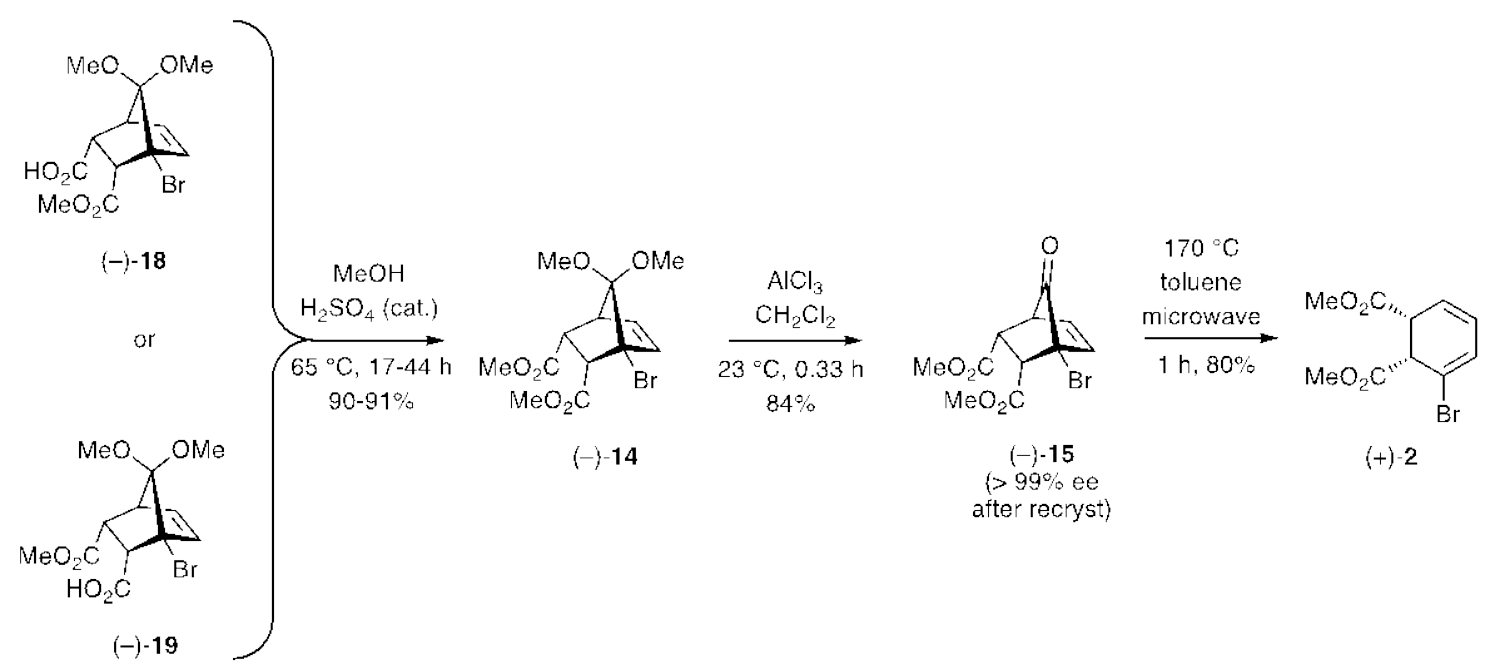

An analogous reaction sequence (Scheme 8) was employed for the purposes of converting the dextrorotatory pair of half esters into compound (-)-2 and involved the intermediacy of the diester $(+)-14$ and the derived keto diester $(+)-\mathbf{1 5}$. 
Scheme 8: The elaboration of the dextrorotatory pair of half-esters into compound (-)-2
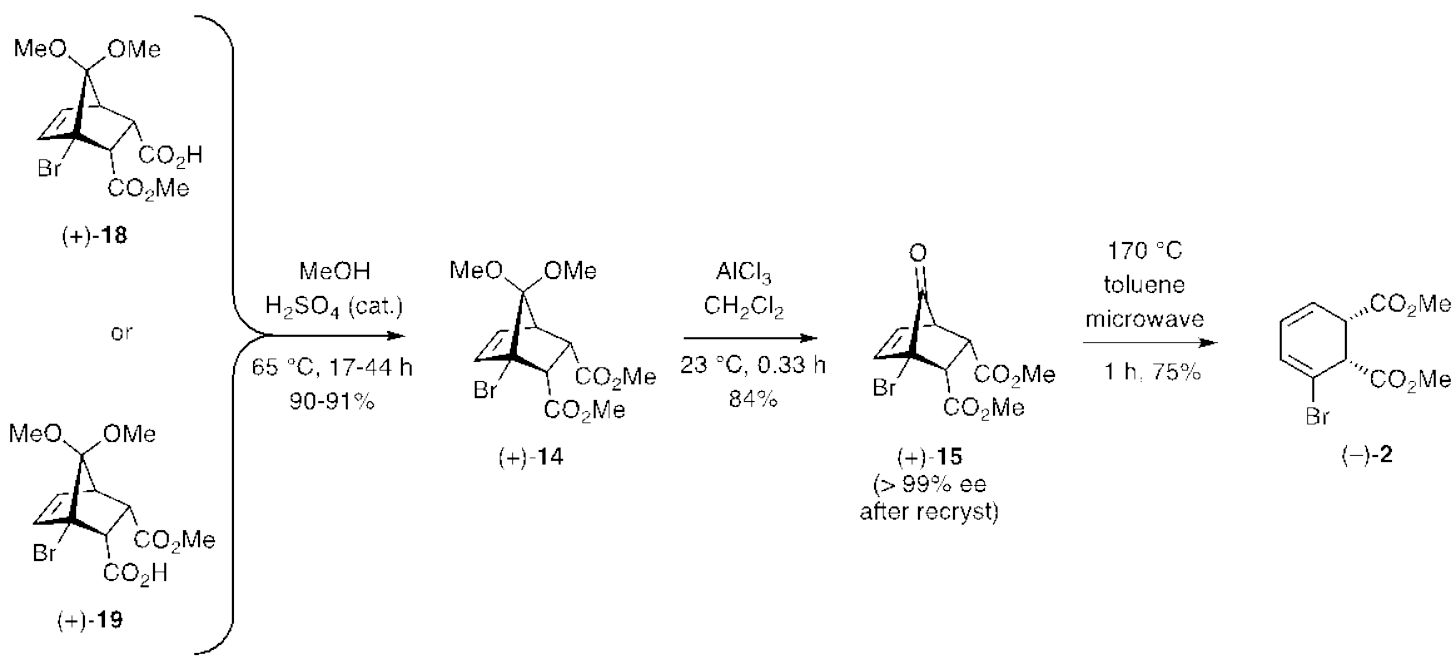

By such means, the target diene-diester was obtained in $75 \%$ chemical yield. The ${ }^{1} \mathrm{H}$ NMR, ${ }^{13} \mathrm{C}\left\{{ }^{1} \mathrm{H}\right\}$ NMR and IR spectral data recorded on product $(-)-2$ matched those reported for its enantiomer $(+)-2$ and the corresponding racemate $( \pm)$-2. Furthermore, the specific rotations of the two enantiomers were of almost the same magnitude but opposite sign $\left\{[\alpha]_{D}=+136 v s-138\right.$ $\left(c=2.0\right.$ in $\mathrm{CHCl}_{3}$ for both) $\}$.

\section{CONCLUSION}

The scalable reaction sequences reported here, which allow for ready access to the title compound and its enantiomer, highlight the utility of Bolm's protocols ${ }^{11}$ for resolving the racemic cyclic anhydride ( \pm )-10 in a highly efficient manner using quinine- or quinidinepromoted methanolyses (so as to produce the relevant half-esters). The exploitation of the enantiomers (+)-2 and (-)-2 in a range of chemical synthesis projects is now underway in our laboratories and results will be reported in due course.

\section{EXPERIMENTAL SECTION}

\section{Synthetic Studies}

General Experimental Procedures. Unless otherwise specified, proton $\left({ }^{1} \mathrm{H}\right)$ and carbon $\left[{ }^{13} \mathrm{C}\left\{{ }^{1} \mathrm{H}\right\}\right]$ NMR spectra were recorded at $18{ }^{\circ} \mathrm{C}$ in base-filtered $\mathrm{CDCl}_{3}$ on Varian spectrometers operating at 300 or $400 \mathrm{MHz}$ for proton and 75 or $100 \mathrm{MHz}$ for carbon nuclei. For ${ }^{1} \mathrm{H}$ NMR spectra, signals arising from the residual protio-forms of the solvent were used as the internal standards. ${ }^{1} \mathrm{H}$ NMR data are recorded as follows: chemical shift (multiplicity, 
coupling constant(s) $J(\mathrm{~Hz})$, relative integral] where multiplicity is defined as: $\mathrm{s}=$ singlet; $\mathrm{d}=$ doublet; $\mathrm{t}$ = triplet; $\mathrm{q}$ = quartet; $\mathrm{m}=$ multiplet or combinations of the above. The signal due to residual $\mathrm{CHCl}_{3}$ appearing at $\delta_{\mathrm{H}} 7.26$ and the central resonance of the $\mathrm{CDCl}_{3}$ "triplet" appearing at $\delta_{\mathrm{C}} 77.16$ were used to reference ${ }^{1} \mathrm{H}$ and ${ }^{13} \mathrm{C}\left\{{ }^{1} \mathrm{H}\right\}$ NMR spectra, respectively. Infrared spectra $\left(v_{\max }\right)$ were normally recorded on a Perkin-Elmer 1800 Series FTIR Spectrometer with samples being analyzed as thin films on $\mathrm{KBr}$ plates. Sometimes, attenuated total reflectance (ATR) IR spectra were recorded on a Bruker Alpha-P instrument with samples being prepared by allowing a $\mathrm{CDCl}_{3}$ solution of these to evaporate on the sampling plate before the spectrum was acquired. Low-resolution ESI mass spectra were recorded on a Micromass LC-ZMD single quadrupole liquid chromatograph-mass spectrometer while highresolution measurements were conducted on an LCT Premier time-of-flight instrument. Lowand high-resolution EI mass spectra were recorded on an Autospec Premier Micromass magnetic-sector machine. Melting points were measured on an Optimelt automated melting point system and are uncorrected. Analytical thin layer chromatography (TLC) was performed on aluminum-backed $0.2 \mathrm{~mm}$ thick silica gel $60 \mathrm{~F}_{254}$ plates as supplied by Merck. Eluted plates were visualized using a $254 \mathrm{~nm}$ UV lamp and/or by treatment with a suitable dip followed by heating. These dips included phosphomolybdic acid: ceric sulfate: sulfuric acid (conc.): water (37.5 g: $7.5 \mathrm{~g}: 37.5 \mathrm{~g}: 720 \mathrm{ml}$ ) or potassium permanganate: potassium carbonate: 5\% sodium hydroxide aqueous solution: water (3 g: $20 \mathrm{~g}$ : $5 \mathrm{ml}$ : $300 \mathrm{ml}$ ). Flash chromatographic separations were carried out following protocols defined by Still et al. ${ }^{13}$ with silica gel $60(40-63 \mu \mathrm{m})$ as the stationary phase and using the AR- or HPLC-grade solvents indicated. Starting materials and reagents were generally available from the Sigma-Aldrich, Merck, TCI, Strem or Lancaster Chemical Companies and were used as supplied. Drying agents and other inorganic salts were purchased from the AJAX, BDH or Unilab Chemical Companies. Tetrahydrofuran (THF), methanol and dichloromethane (DCM) were dried using a Glass Contour solvent purification system that is based upon a technology originally described by Grubbs et al. ${ }^{14}$ Where necessary, reactions were performed under an argon atmosphere and any necessary heating carried out using an oil bath. All microwave irradiation experiments were carried out in a microwave apparatus, operating at a frequency of $2.45 \mathrm{GHz}$ with continuous irradiation power from 0 to $300 \mathrm{~W}$ utilizing the standard absorbance level of $300 \mathrm{~W}$ maximum power. The reactions were carried out in $10 \mathrm{ml}$ sealed vessels with a working volume of $7 \mathrm{ml}$ and equipped with a magnetic stirrer. The temperature was measured with a fibre optic temperature sensor immersed in the reaction vessel. After the irradiation period, the reaction vessel was cooled rapidly (1-2 min) to ambient temperatures by jet 
cooling using nitrogen gas. Optical rotations were measured on a Perkin-Elmer 241 polarimeter at the sodium-D line $(\lambda=589 \mathrm{~nm})$ between 17 to $20^{\circ} \mathrm{C}$ at the concentration $(c)$ (g/100 ml) indicated using spectroscopic grade chloroform as solvent. Measurements were carried out in a cell with a path length (l) of $1 \mathrm{dm}$. Chiral HPLC analyses were conducted using a Daicel ChiralPak AS-H column that was normally eluted with 9:1 v/v hexane/2propanol at a flow rate of $0.5 \mathrm{ml} / \mathrm{min}$. PLE was purchased from commercial sources.

\section{Specific Experimental Procedures and Product Characterization}

1,1-Dimethoxycyclopentane (Compound 4). A magnetically stirred solution of cyclopentanone $(80 \mathrm{ml}, 0.90 \mathrm{~mol})$ and trimethyl orthoformate $(113 \mathrm{ml}, 0.94 \mathrm{~mol})$ in dry methanol $(41 \mathrm{ml})$ was treated with Montmorillonite K 10 (5.00 g of powdered material) and the ensuing mixture heated under reflux for $45 \mathrm{~h}$. The cooled reaction mixture was filtered through Celite ${ }^{\mathrm{TM}}$ and the filtrate subjected to distillation and thus affording ketal $4^{5}$ (73.0 g, 62\%) as a clear, colorless liquid, b.p. =52-56 ${ }^{\circ} \mathrm{C} @ 30$ mm Hg. ${ }^{1} \mathrm{H}$ NMR (300 MHz, $\left.\mathrm{CDCl}_{3}\right)$ $\delta 3.17$ (s, 6H), 1.76-1.68 (complex m, 4H), 1.66-1.57 (complex m, 4H). ${ }^{13} \mathrm{C}\left\{{ }^{1} \mathrm{H}\right\}$ NMR (100 $\left.\mathrm{MHz}, \mathrm{CDCl}_{3}\right) \delta 112.3,49.4,34.3,23.3$.

1,1,3-Tribromo-2,2-dimethoxycyclopentane [Compound ( \pm )-5]. Molecular bromine (21.0 $\mathrm{ml}, 0.35 \mathrm{~mol}$ ) was added, dropwise over $0.25 \mathrm{~h}$, to a magnetically stirred solution of ketal 4 (15.0 g, $0.115 \mathrm{~mol}$ ) in dry methanol/1,4-dioxane (360 ml of 1:5 v/v mixture) maintained at 10 ${ }^{\circ} \mathrm{C}$ in a vessel protected from light. The resulting mixture was allowed to warm to $22{ }^{\circ} \mathrm{C}$ and kept at this temperature, while still being protected from light, for $168 \mathrm{~h}$ then heated at 27-28 ${ }^{\circ} \mathrm{C}$ for $24 \mathrm{~h}$. The resulting clear, light-orange colored solution was cooled then extracted with hexanes $(5 \times 150 \mathrm{ml})$ and the combined organic phases filtered through a plug of cotton wool and the filtrate concentrated at $25-30{ }^{\circ} \mathrm{C}$ under reduced pressure $(15 \mathrm{~mm} \mathrm{Hg})$ to a give lightyellow oil. This was treated with diethyl ether $(100 \mathrm{ml})$ at $30{ }^{\circ} \mathrm{C}$ and the resulting mixture filtered through Celite ${ }^{\mathrm{TM}}$ and the filtrate then concentrated under reduced pressure to $c a$. onethird of its original volume (ie to ca. $30 \mathrm{ml}$ ). The resulting oil was cooled to $-20{ }^{\circ} \mathrm{C}$ and thereby affording compound $( \pm)-5^{6}(20.0 \mathrm{~g}, 47 \%)$ as a white, crystalline solid. Subjection of the mother liquors to flash chromatography (silica, 10:1 v/v hexane/ethyl acetate elution) and concentration of the relevant fractions $\left(R_{\mathrm{f}}=0.4\right)$ afforded additional quantities of compound ( \pm )-5 (4.80 g, 11\%) as a white, crystalline solid, m.p. $=69{ }^{\circ} \mathrm{C} .{ }^{1} \mathrm{H}$ NMR $\left(400 \mathrm{MHz}, \mathrm{CDCl}_{3}\right) \delta$ 4.38 (t, $J=8.7 \mathrm{~Hz}, 1 \mathrm{H}$ ), 3.69 (s, 3H), 3.45 (s, 3H), 2.84-2.75 (complex m, 1H), 2.72-2.62 (complex m, 1H), 2.54-2.44 (complex m, 1H), 2.43-2.32 (complex m, $1 \mathrm{H}$ ). ${ }^{13} \mathrm{C}\left\{{ }^{1} \mathrm{H}\right\} \mathrm{NMR}$ $\left(100 \mathrm{MHz} \mathrm{CDCl}_{3}\right) \delta 104.2,68.6,52.4,51.3,46.9$, 46.2, 33.6. IR $v_{\max }(\mathrm{KBr}) 2983,2944$, 2839, 1450, 1440, 1302, 1208, 1173, 1155, 1094, 1063, 1041, 1010, 985, 938, 848, $820 \mathrm{~cm}^{-1}$. 
HRMS (ESI, +ve) calcd for $\mathrm{C}_{7} \mathrm{H}_{11}{ }^{79} \mathrm{Br}_{3} \mathrm{O}_{2} \mathrm{Na}\left[(\mathrm{M}+\mathrm{Na})^{+}\right]$386.8207, found 386.8218. Anal. calcd for $\mathrm{C}_{7} \mathrm{H}_{11} \mathrm{Br}_{3} \mathrm{O}_{2}$ C, 22.92; $\mathrm{H}, 3.02 ; \mathrm{Br}$, 65.34: found C, 23.16; $\mathrm{H}, 3.01 ; \mathrm{Br}, 65.55 \%$.

1-Bromo-5,5-dimethoxycyclopenta-1,3-diene (Compound 6). A solution of tribromide $( \pm)$ 5 (29.1 g, $80.1 \mathrm{mmol}$ ) in dry THF (50 ml) was added dropwise, over ca. $0.33 \mathrm{~h}$, to a magnetically stirred solution of potassium tert-butoxide (25.0 g, $222.7 \mathrm{mmol})$ in dry THF $(500 \mathrm{ml})$ at maintained $0{ }^{\circ} \mathrm{C}$. After a further $0.25 \mathrm{~h}$ ice $(350 \mathrm{~g})$ and water $(750 \mathrm{ml})$ were added to the reaction mixture that was then extracted with hexane $(5 \times 600 \mathrm{ml})$. The combined organic phases were washed with water $(2 \times 500 \mathrm{ml})$ and brine $(1 \times 350 \mathrm{ml})$ before being dried $\left(\mathrm{Na}_{2} \mathrm{SO}_{4}\right)$ and filtered. The resulting clear and colorless solution containing diene $\mathbf{6}$ was used directly in the next step of the reaction sequence as detailed immediately below.

(rel-3aR,4S,7R,7aS)-2,4-Dibromo-1,1,8,8-tetramethoxy-3a,4,7,7a-tetrahydro-1H-4,7-

methanoindene [Compound ( \pm )-7]. A solution of diene 6 (ca. $5.3 \mathrm{mmol})$ in hexane $(200 \mathrm{ml})$ was stirred at $22{ }^{\circ} \mathrm{C}$ for $36 \mathrm{~h}$ then concentrated under reduced pressure (initially at $40{ }^{\circ} \mathrm{C}$ and $15 \mathrm{~mm} \mathrm{Hg}$ and then at $22{ }^{\circ} \mathrm{C}$ and $0.05 \mathrm{~mm} \mathrm{Hg}$ ). The resulting solid was recrystallized (diethyl ether) to give compound $( \pm)-7(1.00 \mathrm{~g}$, ca. $96 \%)$ as a white, crystalline solid, m.p. $=74-79{ }^{\circ} \mathrm{C}$ (diethyl ether), $R_{\mathrm{f}}=0.8$ (in 1:1 v/v hexane/ethyl acetate). ${ }^{1} \mathrm{H}$ NMR (400 $\left.\mathrm{MHz}, \mathrm{CDCl}_{3}\right) \delta 6.11$ (broad s, 1H), 6.02 (m, 1H), 5.76 (d, $J=6.3 \mathrm{~Hz}, 1 \mathrm{H}$ ), 3.48 (dd, $J=7.4$ and $2.3 \mathrm{~Hz}, 1 \mathrm{H}$ ), 3.44 (s, 6H), 3.33 (s, 3H), 3.32 (s, 3H), $3.05(\mathrm{~m}, 1 \mathrm{H}), 3.00$ (broad s, $1 \mathrm{H}) .{ }^{13} \mathrm{C}\left\{{ }^{1} \mathrm{H}\right\}$ NMR (100 $\left.\mathrm{MHz}, \mathrm{CDCl}_{3}\right) \delta 135.3,134.9,130.4,125.4,117.4,108.8,66.8,57.2,52.6,51.3,50.7(1)$, 50.6(7), 48.5, 46.5. IR $v_{\max }$ 2942, 2834, 1457, 1248, 1132, 1110, 1057, 977, $727 \mathrm{~cm}^{-1}$. MS (ESI, +ve) $\mathrm{m} / \mathrm{z}$ 435, 433 and 431 [(M + Na) 17, 30 and 17\%], 381, 379 and 377 (50, 100 and 50\%), 305 (29), 275 (51), 221 (32), 65 (53). HRMS (ESI, +ve) calcd for $\mathrm{C}_{14} \mathrm{H}_{18}{ }^{79} \mathrm{Br}_{2} \mathrm{O}_{4} \mathrm{Na}$ $\left[(\mathrm{M}+\mathrm{Na})^{+}\right]$430.9464, found 430.9464 .

\section{(rel-3aR,4S,7R,7aS)-2,4-Dibromo-8,8-dimethoxy-3a,4,7,7a-tetrahydro-1H-4,7-metha-}

anoinden-1-one [Compound ( \pm )-8]. Compound $( \pm)-7$ (20 mg, $0.05 \mathrm{mmol})$ was dissolved in $\mathrm{CDCl}_{3}(0.5 \mathrm{ml})$ in an NMR tube. The resulting solution was left standing at $22{ }^{\circ} \mathrm{C}$ until complete consumption of the starting material was observed (usually $96 \mathrm{~h}$ ) as determined by TLC analysis. The solution was then concentrated under reduced pressure to give compound ( \pm )-8 (18 mg, 96\%) as a white, crystalline solid, m.p. = $174{ }^{\circ} \mathrm{C} .{ }^{1} \mathrm{H}$ NMR (400 MHz, $\mathrm{CDCl}_{3}$ ) $\delta 7.64$ (d, $J=2.8 \mathrm{~Hz}, 1 \mathrm{H}$ ), 5.91-5.82 (complex m, 2H), 3.64 (m, 1H), 3.47 (s, 3H), 3.33 (s, 3H), $3.25(\mathrm{~m}, 1 \mathrm{H}), 3.14(\mathrm{t}, J=5.3 \mathrm{~Hz}, 1 \mathrm{H}) .{ }^{13} \mathrm{C}\left\{{ }^{1} \mathrm{H}\right\} \mathrm{NMR}\left(100 \mathrm{MHz}, \mathrm{CDCl}_{3}\right) \delta 200.2$, 158.5, 136.5, 130.8, 128.7, 118.8, 65.3, 52.7, 52.6, 50.8, 47.4, 47.0. IR $v_{\max } 1723,1582$, 1244, 1131, 1113, 1047, 977, 899, $696 \mathrm{~cm}^{-1}$. MS (EI, +ve) $\mathrm{m} / \mathrm{z}$ 366, 364 and 362 [(M) ${ }^{+\bullet} 10$, 18 and 10\%], 351, 349 and 347 (11, 28 and 12), 319, 317 and 315 (54, 100 and 56), 285 and 
283 (98 and 100), 211 and 209 (35 and 38) 145 (39), 102 (64). HRMS (EI, +ve) calcd for $\mathrm{C}_{12} \mathrm{H}_{12}{ }^{79} \mathrm{Br}_{2} \mathrm{O}_{3}\left[(\mathrm{M})^{+\cdot}\right]$ 361.9153, found 361.9151.

(rel-3aR,4R,7R,7aS)-4-Bromo-8,8-dimethoxy-3a,4,7,7a-tetrahydro-4,7-methanoiso-

benzofuran-1,3-dione [Compound ( \pm )-10]. A magnetically stirred solution of diene 6 in hexane (1500 ml, ca. $38 \mathrm{mmol}$ ) was treated with a solution of maleic anhydride (9) (11.8 g, $120 \mathrm{mmol})$ in ethyl acetate $(20 \mathrm{ml})$ and the resulting mixture stirred at $22{ }^{\circ} \mathrm{C}$ for $18 \mathrm{~h}$ then concentrated at $40{ }^{\circ} \mathrm{C}$ and $15 \mathrm{~mm} \mathrm{Hg}$ to give a light-yellow slurry. The excess maleic anhydride was removed through sublimation by heating the slurry at $60^{\circ} \mathrm{C}$ and $0.1 \mathrm{~mm} \mathrm{Hg}$ for $6 \mathrm{~h}$. The residue thus obtained was subjected to flash column chromatography (silica, 1:1 v/v hexanes/ethyl acetate elution) to give, after concentration of the relevant fractions $\left(R_{\mathrm{f}}=0.1\right.$ in 9:1 v/v hexanes/ethyl acetate), compound ( \pm )-10 (8.5 g, ca. 74\%) as a white, crystalline solid, m.p. $=116-118{ }^{\circ} \mathrm{C} .{ }^{1} \mathrm{H}$ NMR (400 MHz, $\mathrm{CDCl}_{3}$ ) $\delta$ 6.29-6.22 (complex m, 2H), 3.83-3.73 (complex m, 2H), 3.48 (s, 3H), 3.38-3.32 (complex m, 4H). ${ }^{13} \mathrm{C}\left\{{ }^{1} \mathrm{H}\right\}$ NMR $(100 \mathrm{MHz}$, $\left.\mathrm{CDCl}_{3}\right) \delta 170.0,168.5,139.2,131.2,119.1,62.5,53.4,52.1,51.2,46.5,46.1 . \mathrm{IR} v_{\max } 1864$, 1782, 1245, 1117, $920 \mathrm{~cm}^{-1}$. MS (EI, +ve) m/z 304 and $302\left(\mathrm{M}^{+\bullet}\right.$, both 4\%), 276 and 274 (10 and 11), 273 and 271 (both 6), 231 and 229 (99 and 100), 223 (91), 179 (32), 151 (82), 105 (63), 91 (39), 77 (92). HRMS calcd for $\mathrm{C}_{11} \mathrm{H}_{11}{ }^{79} \mathrm{BrO}_{5} \mathrm{M}^{+\bullet}$ found 301.9790, found 301.9790.

\section{(rel-3aR,4R,7R,7aS)-4-Bromo-3a,4,7,7a-tetrahydro-4,7-methanoisobenzofuran-1,3,8-}

trione [Compound ( \pm -11]. A mixture of the ketal $( \pm)-\mathbf{1 0}(1.03 \mathrm{~g}, 3.40 \mathrm{mmol})$ and $\mathrm{AlCl}_{3}$ ( $2.71 \mathrm{~g}, 20.3 \mathrm{mmol}$ ) was cooled to $0{ }^{\circ} \mathrm{C}$ then treated with dichloromethane $(40 \mathrm{ml})$ and the resulting slurry stirred at $0{ }^{\circ} \mathrm{C}$ for $0.08 \mathrm{~h}$ then at $22{ }^{\circ} \mathrm{C}$ for $0.33 \mathrm{~h}$ before being poured into a vigorously stirred mixture of ice (30 g) and brine $(30 \mathrm{ml})$. The ensuing mixture was extracted with diethyl ether $(1 \times 100 \mathrm{ml})$ and the separated aqueous phase diluted with $\mathrm{HCl}(50 \mathrm{ml}$ of a $1 \mathrm{M}$ aqueous solution) then extracted with diethyl ether $(2 \times 50 \mathrm{ml})$. The combined organic phases were washed with brine $(1 \times 50 \mathrm{ml})$ before being dried $\left(\mathrm{Na}_{2} \mathrm{SO}_{4}\right)$, filtered and concentrated under reduced pressure at $40^{\circ} \mathrm{C}$ to a light-yellow solid. Recrystallization of this material [from chloroform that had been filtered through alumina (to remove any ethanol)] gave compound ( \pm )-11 (590 mg, 68\%) as a white, crystalline solid, m.p. $=142{ }^{\circ} \mathrm{C}, R_{\mathrm{f}}=0.2$ (in 1:1 v/v hexane/ethyl acetate). ${ }^{1} \mathrm{H}$ NMR (300 MHz, $\left.\mathrm{CDCl}_{3}\right) \delta$ 6.75-6.74 (complex m, 2H), 3.85 (m, 1H), 3.80-3.71 (complex m, 2H). ${ }^{13} \mathrm{C}\left\{{ }^{1} \mathrm{H}\right\}$ NMR (75 MHz, $\left.\mathrm{CDCl}_{3}\right) \delta 189.0,167.8$, 166.7, 137.1, 132.1, 56.9, 48.8, 45.2, 43.5. IR $v_{\max }$ 1782, 1230, 1095, $927 \mathrm{~cm}^{-1}$. MS (ESI, ve) $m / z 307$ and $305\left[\left(\mathrm{M}-\mathrm{H}+\mathrm{MeOH}+\mathrm{H}_{2} \mathrm{O}\right)^{-}\right.$, both 100\%], 275 and $273\left[\left(\mathrm{M}-\mathrm{H}+\mathrm{H}_{2} \mathrm{O}\right)^{-}\right.$, 
both 53]. HRMS (ESI, +ve) calcd for $\mathrm{C}_{10} \mathrm{H}_{10} \mathrm{BrO}_{5}\left[(\mathrm{M}+\mathrm{H}+\mathrm{MeOH})^{+}\right]$288.9706, found 288.9703. Anal. calcd for $\mathrm{C}_{9} \mathrm{H}_{5} \mathrm{BrO}_{4}$ C, 42.06; H, 1.96: found C, 42.01; H, 2.12\%.

(rel-3aR,7aS)-4-Bromo-3a,7a-dihydroisobenzofuran-1,3-dione [Compound ( \pm )-12]. A magnetically stirred solution of ketone $( \pm)-\mathbf{1 1}(99.7 \mathrm{mg}, 0.39 \mathrm{mmol})$ in dry $\boldsymbol{o}$-xylene $(5.0 \mathrm{ml})$ was heated under reflux for $0.5 \mathrm{~h}$ then cooled and concentrated under reduced pressure at 40 ${ }^{\circ} \mathrm{C}$ to give a light-yellow oil. Kugelrohr distillation of this material afforded compound $( \pm)-\mathbf{1 2}$ (68.0 mg, 78\%) as a clear, colorless oil, b.p. $=90{ }^{\circ} \mathrm{C}$ at $0.08 \mathrm{~mm} \mathrm{Hg}, R_{\mathrm{f}}=0.1$ (in 3:1 v/v hexane/ethyl acetate). ${ }^{1} \mathrm{H}$ NMR (300 $\left.\mathrm{MHz} \mathrm{CDCl}_{3}\right) \delta 6.53$ (m, 1H), 6.00 (ddd, $J=9.7,6.3$ and $0.5 \mathrm{~Hz}, 1 \mathrm{H}$ ), 5.86-5.76 (complex m, 1H), 4.25-4.06 (complex m, $2 \mathrm{H}) .{ }^{13} \mathrm{C}\left\{{ }^{1} \mathrm{H}\right\} \mathrm{NMR}(75$ $\left.\mathrm{MHz} \mathrm{CDCl}_{3}\right) \delta 169.8,168.9,127.5,125.2,117.5,113.7,47.8$, 44.4. IR $v_{\max }(\mathrm{KBr}) 3084$, 2956, 2925, 2854, 1868, 1783, 1743, 1649, 1584, 1277, 1209, 1094, 1072, 958, $777 \mathrm{~cm}^{-1}$. Anal. calcd for $\mathrm{C}_{8} \mathrm{H}_{5} \mathrm{BrO}_{3} \mathrm{C}$, 41.95; H, 2.20; $\mathrm{Br}$, 34.89: found C, 42.12; H, 2.20; $\mathrm{Br}, 34.94 \%$. Satisfactory MS and HRMS data could not be obtained on this compound.

Dimethyl (rel-1R,2R,3S,4R)-1-Bromo-7,7-dimethoxybicyclo[2.2.1]hept-5-ene-2,3-dicarboxylate [Compound ( \pm )-14]. A magnetically stirred solution of anhydride $( \pm)$-10 (8.66 g, $28.6 \mathrm{mmol})$ in methanol $(150 \mathrm{ml})$ containing $\mathrm{H}_{2} \mathrm{SO}_{4}(1 \mathrm{ml}$ of $98 \%$ material) was heated under reflux for $48 \mathrm{~h}$ then cooled to $40{ }^{\circ} \mathrm{C}$ and concentrated under reduced pressure. The cooled residue was treated with $\mathrm{NaHCO}_{3}(100 \mathrm{ml}$ of a saturated aqueous solution) then extracted with diethyl ether $(3 \times 100 \mathrm{ml})$. The combined organic phases were dried $\left(\mathrm{Na}_{2} \mathrm{SO}_{4}\right)$, filtered and concentrated under reduced pressure to give a white, crystalline solid on cooling the initially obtained oil to $-20^{\circ} \mathrm{C}$. Recrystallization (hexane) of this material gave compound ( \pm )-14 (9.29 g, 93\%) as a colorless, crystalline solid, m.p. $=80{ }^{\circ} \mathrm{C}, R_{\mathrm{f}}=0.25$ (in 3:1 v/v hexane/ethyl acetate). ${ }^{1} \mathrm{H}$ NMR (400 MHz, $\left.\mathrm{CDCl}_{3}\right) \delta 6.27$ (d, $\left.J=6.2 \mathrm{~Hz}, 1 \mathrm{H}\right), 6.13(\mathrm{~m}, 1 \mathrm{H})$, 3.74-3.65 (complex m, 5H), 3.60 (s, 3H), 3.47 (s, 3H), 3.32 (s, 3H), $3.10(\mathrm{~m}, 1 \mathrm{H}) .{ }^{13} \mathrm{C}\left\{{ }^{1} \mathrm{H}\right\}$ NMR (100 MHz, $\left.\mathrm{CDCl}_{3}\right) \delta 171.2,170.7,139.0,129.1,115.0,65.7,53.7,53.2,52.1,50.9$, 49.0, 47.0 (one resonance obscured or overlapping). IR $v_{\max } 2952,2922,2849,1747,1435$, 1332, 1258, 1199, 1116, 1092, 1050, 1020, $798 \mathrm{~cm}^{-1}$. MS (ESI, +ve) m/z 371 and 373 [(M + $\mathrm{Na})^{+} 83$ and 100\%], 317 (6), 199 (5). HRMS (ESI, +ve) calcd for $\mathrm{C}_{13} \mathrm{H}_{17}{ }^{79} \mathrm{BrO}_{6} \mathrm{Na}[(\mathrm{M}+$ $\mathrm{Na})^{+}$] 371.0106, found 371.0099. Anal. calcd for $\mathrm{C}_{13} \mathrm{H}_{17} \mathrm{BrO}_{6}$ : C, 44.72; $\mathrm{H}, 4.91 ; \mathrm{Br}, 22.88$ : found C, 44.84; H, 4.96; Br, 22.83\%.

Subjection of this material to chiral HPLC analysis as detailed in the General Experimental Procedures section allowed for the separation of the constituent enantiomers. These had retention times of 12.0 and 15.6 min (see Figure S10). 


\section{Dimethyl (rel-1R,2R,3S,4R)-1-Bromo-7-oxobicyclo[2.2.1]hept-5-ene-2,3-dicarboxylate}

[Compound ( \pm )-15]. $\mathrm{AlCl}_{3}(7.30 \mathrm{~g}, 54.7 \mathrm{mmol})$ was added, in one portion, to a vigorously stirred solution of ketal $( \pm)-14(2.04 \mathrm{~g}, 5.84 \mathrm{mmol})$ in dry dichloromethane $(70 \mathrm{ml})$ maintained at $22{ }^{\circ} \mathrm{C}$. After $0.33 \mathrm{~h}$ the reaction mixture was rapidly poured onto a mixture of ice (200 g) and diethyl ether $(250 \mathrm{ml})$ and the resulting slush treated with $\mathrm{HCl}$ (300 $\mathrm{ml}$ of a 1 $\mathrm{M}$ aqueous solution). The separated aqueous phase was extracted with diethyl ether $(3 \times 150$ $\mathrm{ml})$ and the combined organic phases washed with brine $(1 \times 100 \mathrm{ml})$ before being dried $\left(\mathrm{Na}_{2} \mathrm{SO}_{4}\right)$, filtered and concentrated under reduced pressure. The ensuing white, crystalline solid was recrystallized (diethyl ether/hexane) to give compound ( \pm )-15 (1.49 g 84\%) as colorless needles, m.p. $=86-88^{\circ} \mathrm{C}, R_{\mathrm{f}}=0.5$ (in $1: 1 \mathrm{v} / \mathrm{v}$ hexane/ethyl acetate). ${ }^{1} \mathrm{H}$ NMR (400 $\left.\mathrm{MHz}, \mathrm{CDCl}_{3}\right) \delta 6.65$ (d, $\left.J=6.8 \mathrm{~Hz}, 1 \mathrm{H}\right), 6.60$ (m, 1H), 3.74 (s, 3H), 3.68-3.62 (complex m, 4H), 3.51 (d, $J=10.7 \mathrm{~Hz}, 1 \mathrm{H}), 3.40$ (broad s, $1 \mathrm{H}) .{ }^{13} \mathrm{C}\left\{{ }^{1} \mathrm{H}\right\}$ NMR (100 MHz, $\mathrm{CDCl}_{3}$ ) $\delta$ 191.9, 169.4, 169.3, 136.0, 130.2, 60.7, 52.6(0), 52.5(8), 51.4, 47.0, 46.6. IR $v_{\max } 2953$, 1741, 1739, 1436, 1328, 1200, 1124, $1044 \mathrm{~cm}^{-1}$. MS (ESI, +ve) $\mathrm{m} / \mathrm{z} 357$ and 359 [(M + Na + $\mathrm{MeOH})^{+} 79$ and 78\%], 335 and $337\left[(\mathrm{M}+\mathrm{H}+\mathrm{MeOH})^{+} 72\right.$ and 71\%], 303 and $305\left[(\mathrm{M}+\mathrm{H})^{+}\right.$ 100 and 98\%], 157 (60), 101 (28), 79 (59). HRMS (ESI, +ve) calcd for $\mathrm{C}_{11} \mathrm{H}_{12}{ }^{79} \mathrm{BrO}_{5}(\mathrm{M}+$ $\mathrm{H})^{+}$302.9863, found 302.9868.

\section{Dimethyl (rel-1S,2R)-3-Bromocyclohexa-3,5-diene-1,2-dicarboxylate [Compound ( \pm )-2].}

Freshly distilled ketone $( \pm)-\mathbf{1 5}(513 \mathrm{mg}, 1.69 \mathrm{mmol})$ maintained under an atmosphere of nitrogen in a kugelrohr oven was heated at $220-230{ }^{\circ} \mathrm{C}$ for 5 minutes at which point gas evolution had ceased. The resulting light-yellow oil was then distilled, at $0.1 \mathrm{~mm} \mathrm{Hg}$, over a period of 5 minutes and the cooled distillate subjected to flash chromatography (silica, 3:1 v/v hexane/ethyl acetate elution) to give, after concentration of the relevant fractions $\left(R_{\mathrm{f}}=0.4\right.$ in 4:1 v/v hexane/ethyl acetate), diene $( \pm)-2(350 \mathrm{mg}, 75 \%)$ as a clear, colorless oil, b.p. $=40{ }^{\circ} \mathrm{C}$ @ $0.07 \mathrm{~mm} \mathrm{Hg} .{ }^{1} \mathrm{H}$ NMR (300 MHz, $\left.\mathrm{CDCl}_{3}\right) \delta 6.41$ (m, 1H), 6.24 (m, 1H), 5.85 (m, 1H), 3.82 (td, $J=7.6$ and $2.8 \mathrm{~Hz}, 1 \mathrm{H}), 3.77$ (d, $J=7.6 \mathrm{~Hz}, 1 \mathrm{H}), 3.75$ (s, $3 \mathrm{H}), 3.69$ (s, $3 \mathrm{H}) .{ }^{13} \mathrm{C}\left\{{ }^{1} \mathrm{H}\right\}$ NMR (75 MHz, $\left.\mathrm{CDCl}_{3}\right) \delta 171.0,169.6,129.0,124.2,124.1,117.6,52.6,52.5,49.3$, 44.0. IR $v_{\max }(\mathrm{KBr}) 3058,3001,2953,2844,1740,1638,1571,1435,1328,1288,1244,1202,1107$, 1033, 1001, 961, 937, 897, 873, 839, 808, 750, 718, $698 \mathrm{~cm}^{-1}$. MS (EI, +ve) m/z 276 and 274 [(M) 9 and 10\%], 243 and 241 (6 and 5), 217 and 215 (21 and 22), 185 and 183 (17 and 18), 173 and 171 (18 and 19), 92 (48), 84 (43), 77 (100). HRMS (EI, +ve) calcd for $\mathrm{C}_{10} \mathrm{H}_{11}{ }^{79} \mathrm{BrO}_{4}$ $\left[(\mathrm{M})^{+\bullet}\right] 273.9841$, found 273.9843 . 
PLE-Mediated Saponification of Diester ( \pm )-14. Formation of EnantiomericallyEnriched Diester Dimethyl (1R,2R,3S,4R)-1-Bromo-7,7-dimethoxybicyclo[2.2.1]hept-5ene-2,3-dicarboxylate [(+)-14] and Half-Ester (1S,2R,3S,4S)-4-Bromo-7,7-dimethoxy-3(methoxycarbonyl)bicyclo[2.2.1]hept-5-ene-2-carboxylic acid [(-)-18]. A magnetically stirred solution of diester $( \pm)-\mathbf{1 4}(36.9 \mathrm{mg}, 0.106 \mathrm{mmol})$ in acetone $(0.3 \mathrm{ml})$ was treated with a solution of PLE (5.0 mg, 120 units) in $\mathrm{pH} 8.0$ sodium phosphate buffer ( $3.0 \mathrm{ml}$ of a $0.1 \mathrm{M}$ aqueous solution). The resulting suspension was stirred at $31-33{ }^{\circ} \mathrm{C}$ for $48 \mathrm{~h}$ then a $1.0 \mathrm{ml}$ aliquot of the reaction mixture was diluted with $\mathrm{HCl}(1.0 \mathrm{ml}$ of $1 \mathrm{M}$ aqueous solution) and the ensuing mixture concentrated under reduced pressure at $40^{\circ} \mathrm{C}$. The residue thus obtained was subjected to flash chromatography (silica, $4: 1 \mathrm{v} / \mathrm{v}$ hexane/ethyl acetate $\rightarrow$ ethyl acetate gradient elution) and thereby affording two fractions, A and B.

Concentration of fraction A ( $R_{\mathrm{f}}=0.25$ in $3: 1 \mathrm{v} / \mathrm{v}$ hexane/ethyl acetate) afforded diester (+)-14 (3.8 mg, 34\%). Chiral HPLC analysis of this material established that it had been obtained in $43 \%$ ee (see Figure S11). The ${ }^{1} \mathrm{H}$ NMR spectral data obtained on it were identical with those derived from the starting material ( \pm )-14.

Concentration of fraction B $\left(R_{\mathrm{f}}=0.2\right.$ in $1: 1 \mathrm{v} / \mathrm{v}$ hexane/ethyl acetate containing $5 \%$ acetic acid) gave compound (-)-18 (5.1 mg, 47\%). The ${ }^{1} \mathrm{H}$ NMR spectral data obtained on this material were identical with those derived from an authentic sample prepared as described below. A solution of this material in methanol/benzene $(2.5 \mathrm{ml}$ of a $4: 1 \mathrm{v} / \mathrm{v}$ mixture) was treated with an excess of $\mathrm{TMSCHN}_{2}$ in diethyl ether and the resulting mixture immediately concentrated under reduced pressure at $40{ }^{\circ} \mathrm{C}$ to give diester $(-)-14$ (5.3 mg, quant.). Chiral HPLC analysis of this material established that it had been obtained in $46 \%$ ee (See Figure S12). The ${ }^{1} \mathrm{H}$ NMR spectral data obtained on this material were identical with those derived from the starting material $( \pm)-14$.

Quinine-mediated Conversion of Anhydride ( \pm )-10 into Half-Esters (1R,2S,3R,4R)-4Bromo-7,7-dimethoxy-3-(methoxycarbonyl)bicyclo[2.2.1]hept-5-ene-2-carboxylic acid

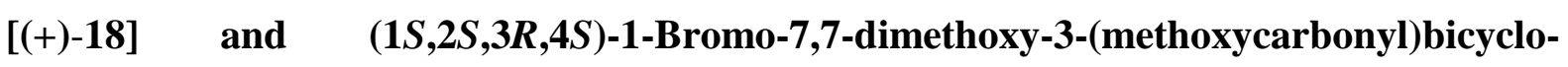
[2.2.1]hept-5-ene-2-carboxylic acid [(-)-19]. Methanol (3.1 ml, $76.5 \mathrm{mmol})$ was added, dropwise, to a magnetically stirred solution of anhydride $( \pm)-\mathbf{1 0}(7.78 \mathrm{~g}, 25.7 \mathrm{mmol})$ and quinine (9.41 g $29.0 \mathrm{mmol}$ ) in toluene/carbon tetrachloride (300 $\mathrm{ml}$ of a $1: 1 \mathrm{v} / \mathrm{v}$ mixture) maintained at $-55{ }^{\circ} \mathrm{C}$. Stirring was continued for $64 \mathrm{~h}$ at this temperature then the reaction mixture was concentrated under reduced pressure at $40{ }^{\circ} \mathrm{C}$. The resulting light-yellow oil was dissolved in ethyl acetate $(50 \mathrm{ml})$ and the solution thus obtained washed with $\mathrm{HCl}(2 \times 50 \mathrm{ml}$ of a $2 \mathrm{M}$ aqueous solution). The separated aqueous phase was extracted with ethyl acetate (2 
$\times 50 \mathrm{ml})$ and the combined organic phases were dried then $\left(\mathrm{Na}_{2} \mathrm{SO}_{4}\right)$, filtered and concentrated under reduced pressure to provide a light-yellow oil that was subjected to preparative reverse-phase HPLC (Alltima C18 $250 \times 22 \mathrm{~mm}$ column, eluting solvent $50 \mathrm{mM}$ AcOH in 3:7 v/v acetonitrile/water, flow rate $11.5 \mathrm{ml} / \mathrm{min}$ ) and so affording two fractions, A and $\mathrm{B}$.

Concentration of the more mobile fraction A and partitioning of the residue between diethyl ether and $\mathrm{HCl}$ (1 $\mathrm{M}$ aqueous solution) so as to remove residual quinine followed by drying $\left(\mathrm{Na}_{2} \mathrm{SO}_{4}\right)$, filtration and concentration of the separated organic phase gave an oil that upon trituration with diethyl ether resulted in the formation of small amounts of a solid that was removed by filtration. Concentration of the mother liquors gave compound $(+)-18$ (3.58 g, 42\%) as a clear, colorless oil, $[\alpha]_{\mathrm{D}}=+81\left(\mathrm{c}=1.0, \mathrm{CHCl}_{3}\right)$. The ${ }^{1} \mathrm{H}$ and ${ }^{13} \mathrm{C}\left\{{ }^{1} \mathrm{H}\right\} \mathrm{NMR}$ spectra acquired on this material were identical to those recorded for enantiomer (-)-18 (see below). Chiral HPLC analysis established that compound (+)-18 had been obtained in 84\% ee (see Figure S13).

Concentration of the less mobile fraction $\mathrm{B}$ and partitioning of the residue between diethyl ether and $\mathrm{HCl}$ (1 $\mathrm{M}$ aqueous solution) so as to remove residual quinine followed by drying $\left(\mathrm{Na}_{2} \mathrm{SO}_{4}\right)$, filtration and concentration of the separated organic phase gave compound $(-)-19(3.62 \mathrm{~g}, 42 \%)$ as a clear, colorless oil, $[\alpha]_{\mathrm{D}}=-83\left(\mathrm{c}=1.0, \mathrm{CHCl}_{3}\right)$. The ${ }^{1} \mathrm{H}$ and ${ }^{13} \mathrm{C}\left\{{ }^{1} \mathrm{H}\right\}$ NMR spectra acquired on this material were identical with those recorded for enantiomer (+)-19 (see below). Chiral HPLC analysis established that compound (-)-19 had been obtained in 97\% ee (see Figure S16).

Quinidine-mediated Conversion of Anhydride ( \pm )-10 into Half-Esters (1S,2R,3S,4S)-4Bromo-7,7-dimethoxy-3-(methoxycarbonyl)bicyclo[2.2.1]hept-5-ene-2-carboxylic acid [(-)-18] and (1R,2R,3S,4R)-1-Bromo-7,7-dimethoxy-3-(methoxycarbonyl)bicyclo[2.2.1]hept-5-ene-2-carboxylic acid [(+)-19]. Methanol (400 $\mu \mathrm{l}$, $9.88 \mathrm{mmol})$ was added, dropwise, to a magnetically stirred suspension of anhydride $( \pm)-10$ (1.00 g, 3.30 mmol) and quinidine $(1.20 \mathrm{~g}, 3.70 \mathrm{mmol})$ in toluene/tetrachloromethane (30 $\mathrm{ml}$ of a $1: 1 \mathrm{v} / \mathrm{v}$ mixture) maintained at $-55{ }^{\circ} \mathrm{C}$. The ensuing mixture was stirred at this temperature for $40 \mathrm{~h}$ then concentrated under reduced pressure at $40{ }^{\circ} \mathrm{C}$. The yellow oil thus obtained was dissolved in ethyl acetate $(50 \mathrm{ml})$ and the resulting solution washed with $\mathrm{HCl}(2 \times 50 \mathrm{ml}$ of a $2 \mathrm{M}$ aqueous solution). The combined aqueous phases were extracted with ethyl acetate $(2 \times$ $50 \mathrm{ml})$ and the combined organic phases then dried $\left(\mathrm{Na}_{2} \mathrm{SO}_{4}\right)$, filtered and concentrated under reduced pressure and thus providing a light-yellow oil. This was comprised of a 1:1 mixture 
of the mono-esters (-)-18 and (+)-19 containing traces of the corresponding diacid. Subjection of a $850 \mathrm{mg}$ sample of this material to preparative reverse-phase HPLC (Altima C18 $250 \times 22 \mathrm{~mm}$ column, eluting solvent $50 \mathrm{mM} \mathrm{AcOH}$ in 3:7 v/v acetonitrile/water, flow rate $11.5 \mathrm{ml} / \mathrm{min}$ ) afforded two fractions, $\mathrm{A}$ and $\mathrm{B}$.

Concentration of the more mobile fraction A and partitioning of the residue between diethyl ether and $\mathrm{HCl}$ (1 $\mathrm{M}$ aqueous solution) so as to remove residual quinidine followed by drying $\left(\mathrm{Na}_{2} \mathrm{SO}_{4}\right)$, filtration and concentration of the separated organic phase gave an oil that upon trituration with diethyl ether resulted in the formation of small amounts of a solid that was removed by filtration. Concentration of the mother liquors gave compound (-)-18 (350 mg, 32\%) as a clear, colorless oil, $R_{\mathrm{f}}=0.2$ (in $1: 1 \mathrm{v} / \mathrm{v}$ hexane/ethyl acetate containing $5 \%$ acetic acid), $[\alpha]_{\mathrm{D}}=-79\left(\mathrm{c}=1.0, \mathrm{CHCl}_{3}\right) .{ }^{1} \mathrm{H} \mathrm{NMR}\left(300 \mathrm{MHz}, \mathrm{CDCl}_{3}\right) \delta 6.31(\mathrm{~m}, 1 \mathrm{H}), 6.10$ (m, 1H), 3.72 (dd, $J=10.2$ and $3.7 \mathrm{~Hz}, 1 \mathrm{H}$ ), 3.65 (d, $J=10.2 \mathrm{~Hz}, 1 \mathrm{H}$ ), 3.64 (s, 3H), 3.46 (s, $3 \mathrm{H}$ ), 3.30 (s, 3H), 3.10 (broad s, 1H) (signal due to carboxylic acid group proton not observed). ${ }^{13} \mathrm{C}\left\{{ }^{1} \mathrm{H}\right\}$ NMR (75 MHz, $\left.\mathrm{CDCl}_{3}\right) \delta 175.0,171.1,138.6,129.6,115.1,65.4,53.6$, 53.2, 52.1, 50.9, 49.4, 46.9. IR $v_{\max }$ 3098, 2950, 2839, 1746, 1716, 1436, 1332, 1252, 1201, 1139, 1118, $1049 \mathrm{~cm}^{-1}$. MS (ESI, -ve) m/z 335 and 333 [(M - H)-, both 100\%], 321 and 319 (both 78). HRMS (ESI, -ve) calcd for $\mathrm{C}_{12} \mathrm{H}_{14}{ }^{79} \mathrm{BrO}_{6}\left[(\mathrm{M}-\mathrm{H})^{-}\right]$332.9968, found 332.9980.

Chiral HPLC analysis established that compound (-)-18 had been obtained in 92\% ee (see Figure S14).

The solid obtained on trituration of the oil arising from the work-up of this reaction proved to be compound $( \pm)$-18 and this was subjected to single-crystal X-ray analysis (see below and the SI for details).

Concentration of the less mobile fraction $\mathrm{B}$ and partitioning of the residue between diethyl ether and $\mathrm{HCl}$ (1 $\mathrm{M}$ aqueous solution) so as to remove residual quinidine followed by drying $\left(\mathrm{Na}_{2} \mathrm{SO}_{4}\right)$, filtration and concentration of the separated organic phase gave compound (+)-19 (0.37 $\mathrm{g}, 33 \%)$ as a clear, colorless oil, $R_{\mathrm{f}}=0.3$ (in $1: 1 \mathrm{v} / \mathrm{v}$ hexane/ethyl acetate containing $5 \%$ acetic acid), $[\alpha]_{\mathrm{D}}=+81\left(\mathrm{c}=1.0, \mathrm{CHCl}_{3}\right) .{ }^{1} \mathrm{H} \mathrm{NMR}\left(300 \mathrm{MHz}, \mathrm{CDCl}_{3}\right) \delta 6.23$ (m, 1H), 6.15 (m, 1H), 3.73-3.67 (complex m, 2H), 3.59 (s, 3H), 3.46 (s, 3H), 3.31 (s, 3H), 3.10 (broad s, 1H) (signal due to carboxylic acid group proton not observed). ${ }^{13} \mathrm{C}\left\{{ }^{1} \mathrm{H}\right\}$ NMR $\left(75 \mathrm{MHz}, \mathrm{CDCl}_{3}\right) \delta 176.2,170.6,139.5,128.8,115.0,65.4,53.7,53.2,52.1,50.9,48.8,47.1$. IR $v_{\max } 2950,1744,1716,1436,1327,1251,1211,1138,1118,1048,972 \mathrm{~cm}^{-1}$. MS (ESI, ve) $\mathrm{m} / \mathrm{z} 335$ and 333 [(M - H)-, both 100\%], 321 and 319 (both 19). HRMS (ESI, -ve) calcd for $\mathrm{C}_{12} \mathrm{H}_{14}{ }^{79} \mathrm{BrO}_{6}\left[(\mathrm{M}-\mathrm{H})^{-}\right]$332.9968, found 332.9980. 
Chiral HPLC analysis established that compound (+)-19 had been obtained in enantiomerically pure form (see Figure S15).

Preparative Scale Syntheses of Compounds Dimethyl (1S,2S,3R,4S)-1-Bromo-7,7dimethoxybicyclo[2.2.1]hept-5-ene-2,3-dicarboxylate [(-)-14] and Dimethyl $(1 R, 2 R, 3 S, 4 R)-1-B r o m o-7,7-d i m e t h o x y b i c y c l o[2.2 .1]$ hept-5-ene-2,3-dicarboxylate $\quad[(+)-$ 14]

(a) From half-esters (-)-18 or (+)-18: A magnetically stirred solution of compound (-)-18 or (+)-18 in methanol (5.2 ml/mmol) was treated with $\mathrm{H}_{2} \mathrm{SO}_{4}(30 \mu \mathrm{l}$ of $98 \%$ material $/ \mathrm{mmol})$ and the resulting solution heated under reflux for $14 \mathrm{~h}$ then cooled to $40{ }^{\circ} \mathrm{C}$ and concentrated under reduced pressure. The cooled residue was treated with $\mathrm{NaHCO}_{3}(3.5 \mathrm{ml}$ of a saturated aqueous solution/mmol) and extracted with diethyl ether $(3 \times 3.5 \mathrm{ml} / \mathrm{mmol})$. The combined organic phases were then dried $\left(\mathrm{Na}_{2} \mathrm{SO}_{4}\right)$, filtered and concentrated under reduced pressure to give a light-yellow oil. Subjection of this material to flash chromatography (silica, 3:1 v/v hexane/ethyl acetate elution) and concentration of the relevant fractions $\left(R_{\mathrm{f}}=0.25\right.$ in $4: 1 \mathrm{v} / \mathrm{v}$ hexane/ethyl acetate) then gave diester (-)-14 [from (-)-18] or (+)-14 [from (+)-18] (both $91 \%)$ as a clear, colorless oil, $[\alpha]_{\mathrm{D}}=-82\left(\mathrm{c}=2.0, \mathrm{CHCl}_{3}\right)$ and $+83\left(\mathrm{c}=2.0, \mathrm{CHCl}_{3}\right)$, respectively. The ${ }^{1} \mathrm{H}$ and ${ }^{13} \mathrm{C}\left\{{ }^{1} \mathrm{H}\right\}$ NMR spectra acquired on these materials were identical to those recorded for the racemate $( \pm)-\mathbf{1 4}$ (see above). Chiral HPLC analysis of each of compounds (-)-14 and (+)-14 under the same conditions used for resolution of the racemate established that these had been obtained in $97 \%$ and $>99 \%$ ee, respectively (see Figures S17 and S20).

(b) From half-esters (-)-19 or (+)-19: A solution of half-ester (-)-19 or (+)-19 in methanol (5.2 $\mathrm{ml} / \mathrm{mmol}$ ) was treated with $\mathrm{H}_{2} \mathrm{SO}_{4}(30 \mu \mathrm{l}$ of $98 \%$ material $/ \mathrm{mmol}$ ) and the resulting solution heated under reflux for $44 \mathrm{~h}$ then cooled to $40{ }^{\circ} \mathrm{C}$ and concentrated under reduced pressure. The residue thus obtained was treated with $\mathrm{NaHCO}_{3}(3.5 \mathrm{ml}$ of a saturated aqueous solution/mmol) and extracted with diethyl ether $(3 \times 3.5 \mathrm{ml} / \mathrm{mmol})$. The combined organic phases were dried $\left(\mathrm{Na}_{2} \mathrm{SO}_{4}\right)$, filtered and concentrated under reduced pressure to give a lightyellow oil. Subjection of this material to flash chromatography (silica, 3:1 v/v hexane/ethyl acetate elution) and concentration of the relevant fractions $\left(R_{\mathrm{f}}=0.25\right.$ in $4: 1 \mathrm{v} / \mathrm{v}$ hexane/ethyl acetate) then gave diester (-)-14 [from (-)-19] or (+)-14 [from (+)-19] (both 90\%) as a clear, colorless oil. The ${ }^{1} \mathrm{H}$ and ${ }^{13} \mathrm{C}\left\{{ }^{1} \mathrm{H}\right\}$ NMR spectra acquired on these materials were identical to those recorded for the racemate $( \pm)-\mathbf{1 4}$ (see above). Chiral HPLC analysis of each of 
compounds (-)-14 and (+)-14 under the conditions defined above for the resolution of the racemate established that they had been obtained in $97 \%$ and $95 \%$ ee, respectively (see Figures S18 and S19).

Dimethyl (1S,2S,3R,4S)-1-Bromo-7-oxobicyclo[2.2.1]hept-5-ene-2,3-dicarboxylate [(-)15] and Dimethyl (1R,2R,3S,4R)-1-Bromo-7-oxobicyclo[2.2.1]hept-5-ene-2,3dicarboxylate [(+)-15]. Treatment of compound (-)-14 or (+)-14 with $\mathrm{AlCl}_{3}$ in dichloromethane under the same conditions as employed for effecting the conversion $( \pm)-\mathbf{1 4}$ $\rightarrow( \pm$ )-15 (see above) afforded, after workup, a white solid. Recrystallisation (diethyl ether) of each of these materials gave compounds (-)-15 and (+)-15 (84\%) as a white, crystalline solid, m.p. $=118{ }^{\circ} \mathrm{C},[\alpha]_{\mathrm{D}}=+91\left(\mathrm{c}=2.0, \mathrm{CHCl}_{3}\right)$ and $-89\left(\mathrm{c}=2.0, \mathrm{CHCl}_{3}\right)$, respectively. The ${ }^{1} \mathrm{H}$ and ${ }^{13} \mathrm{C}\left\{{ }^{1} \mathrm{H}\right\}$ NMR spectra acquired on these materials were identical to those recorded for the racemate $( \pm)$-15 (see above). Chiral HPLC analysis of each of compounds (-)-15 and (+)15 established that they had each been obtained in $\geq 98 \%$ ee (see Figures S21-S24)

Dimethyl (1R,2S)-3-Bromocyclohexa-3,5-diene-1,2-dicarboxylate [(+)-2]. A magnetically stirred solution of compound (-)-15 (12 mg, $0.04 \mathrm{mmol})$ in dry toluene (2 ml) was irradiated in a microwave reactor for $1 \mathrm{~h}$ at $300 \mathrm{~W}$. The maximum temperature reached was $170{ }^{\circ} \mathrm{C}$. The reaction mixture was then cooled down to room temperature and residual solvents were evaporated under reduced pressure. The residue thus obtained was subjected to column chromatography (silica, 3:1 v/v hexane/ethyl acetate elution) to afford, after concentration of the relevant fractions $\left(R_{\mathrm{f}}=0.25\right.$ in 3:1 v/v hexane/ethyl acetate) compound $(+)-2(9 \mathrm{mg}, 80 \%)$ as a clear, colorless oil, $[\alpha]_{\mathrm{D}}=+136\left(\mathrm{c}=2.0, \mathrm{CHCl}_{3}\right)$. The ${ }^{1} \mathrm{H}$ and ${ }^{13} \mathrm{C}\left\{{ }^{1} \mathrm{H}\right\} \mathrm{NMR}$ spectra acquired on this material were identical to those recorded for the racemate ( \pm )-2 (see above).

Dimethyl (1S,2R)-3-Bromocyclohexa-3,5-diene-1,2-dicarboxylate [(-)-2]. Thermolysis of compound (+)-15 (50 mg, $0.16 \mathrm{mmol})$ in dry toluene $(4 \mathrm{ml})$ under the same conditions as employed for effecting the conversion $(-)-15 \rightarrow(+)-2$ (see above) afforded, compound (-)-2 (34 mg, 75\%) as a clear, colorless oil, $[\alpha]_{\mathrm{D}}=-138$ (c = 2.0, $\left.\mathrm{CHCl}_{3}\right)$. The ${ }^{1} \mathrm{H}$ and ${ }^{13} \mathrm{C}\left\{{ }^{1} \mathrm{H}\right\}$ NMR spectra acquired on this material were identical to those recorded for the racemate $( \pm)-2$ (see above).

\section{Crystallographic Studies}

\section{Crystallographic Data for Compound ( \pm )-5}

$\mathrm{C}_{7} \mathrm{H}_{11} \mathrm{Br}_{3} \mathrm{O}_{2}, M=366.88, T=200 \mathrm{~K}$, monoclinic, space group $P 2_{1} / n, Z=4, a=6.9409(1), b=$ 15.7302(3), $c=9.9702(2) ; \beta=101.3390(13)^{\circ} ; V=1067.32(3) \AA^{3}, D_{x}=2.283 \mathrm{~g} \mathrm{~cm}^{-3}, 2434$ 
unique data $\left(2 \theta_{\max }=54.966^{\circ}\right), R=0.0173$ [for 1791 reflections with $I>2.0 \sigma(I)$ ]; $R w=0.0206$ (all data), $S=1.1172$.

\section{Crystallographic Data for Compound ( \pm )-7}

$\mathrm{C}_{14} \mathrm{H}_{18} \mathrm{Br}_{2} \mathrm{O}_{4}, M=410.08, T=150 \mathrm{~K}$, monoclinic, space group $P 21 / \mathrm{n}, Z=4, a=8.15210(10), b$ $=20.5650(3), c=9.36020(10) ; \beta=100.207(2)^{\circ} ; V=1544.38(4) \AA^{3}, D_{x}=1.764 \mathrm{~g} \mathrm{~cm}^{-3}, 3122$ unique data $\left(2 \theta_{\max }=147.782^{\circ}\right), R=0.0280$ [for 2970 reflections with $I>2.0 \sigma(I)$ ]; $R w=0.0739$ (all data), $S=1.061$.

\section{Crystallographic Data for Compound ( \pm )-8}

$\mathrm{C}_{12} \mathrm{H}_{12} \mathrm{Br}_{2} \mathrm{O}_{3}, M=364.03, T=200 \mathrm{~K}$, monoclinic, space group $C 2 / c, Z=8, a=25.0604(6)$, $b=6.8563(1), c=16.3144(4) \AA ; \beta=117.1426(11)^{\circ} ; V=2494.46(10) \AA^{3}, D_{x}=1.939 \mathrm{~g} \mathrm{~cm}^{-3}$, 3655 unique data $\left(2 \theta_{\max }=60.074^{\circ}\right), R=0.0256$ [for 2668 reflections with $I>3.0 \sigma(I)$ ]; $R w=$ 0.0281 (all data), $S=1.1159$.

\section{Crystallographic Data for Compound ( \pm )-10}

$\mathrm{C}_{11} \mathrm{H}_{11} \mathrm{BrO}_{5}, M=303.11, T=150 \mathrm{~K}$, triclinic, space group $P-1, Z=2, a=6.5865(2), b=$ 7.7172(2), $c=11.3941(3) \AA ; \alpha=96.393(2)^{\circ}, \beta=94.181(2), \gamma=91.513$ (2); $V=$ 573.67(3) $\AA^{3}, D_{x}=1.755 \mathrm{~g} \mathrm{~cm}^{-3}, 3005$ unique data $\left(2 \theta_{\max }=59.82^{\circ}\right), R=0.0323$ [for 2671 reflections with $I>3.0 \sigma(I)] ; R w=0.0712$ (all data), $S=1.081$.

\section{Crystallographic Data for Compound ( \pm )-11}

$\mathrm{C}_{9} \mathrm{H}_{5} \mathrm{BrO}_{4}, M=257.04, T=200 \mathrm{~K}$, triclinic, space group $P-1, Z=4, a=6.7082(3), b=$ 11.1166(6), $c=13.0305(9) \AA ; \alpha=111.034(2)^{\circ}, \beta=99.534(3), \gamma=11.745(3) ; V=861.93(8)$ $\AA^{3}, D_{x}=1.981 \mathrm{~g} \mathrm{~cm}^{-3}, 3963$ unique data $\left(2 \theta_{\max }=55.076^{\circ}\right), R=0.0340$ [for 2603 reflections with $I>3.0 \sigma(I)] ; R w=0.0345$ (all data), $S=1.1327$.

\section{Crystallographic Data for Compound ( \pm )-14}

$\mathrm{C}_{13} \mathrm{H}_{17} \mathrm{BrO}_{6}, M=349.18, T=200 \mathrm{~K}$, orthorhombic, space group Pbca, $Z=8, a=9.9701(2)$, $b=14.1002(2), c=21.0590(4) \AA ; V=2960.48(9) \AA^{3}, D_{x}=1.567 \mathrm{~g} \mathrm{~cm}^{-3}, 3397$ unique data $\left(2 \theta_{\max }=54.964^{\circ}\right), R=0.0299$ [for 1997 reflections with $I>3.0 \sigma(I)$ ]; $R w=0.0372$ (all data), $S=1.0958$.

\section{Crystallographic Data for Compound ( \pm )-15}

$\mathrm{C}_{11} \mathrm{H}_{11} \mathrm{BrO}_{5}, M=303.11, T=200 \mathrm{~K}$, tetragonal, space group $P 4_{1}, Z=4, a=10.9119(3), \mathrm{b}=$ 10.9119(3), $c=10.0504(3) \AA ; V=1196.70(8) \AA^{3}, D_{x}=1.682 \mathrm{~g} \mathrm{~cm}^{-3}, 2215$ unique data $\left(2 \theta_{\max }=140.722^{\circ}\right), R=0.0225$ [for 2079 reflections with $I>3.0 \sigma(I)$ ]; $R w=0.0911$ (all data), $S=1.053$.

\section{Crystallographic Data for Compound (-)-15}


$\mathrm{C}_{11} \mathrm{H}_{11} \mathrm{BrO}_{5}, M=303.11, T=200 \mathrm{~K}$, tetragonal, space group $P 4_{1}, Z=4, a=10.9469(3), c=$ 10.0775(2) $\AA ; V=1207.63(5) \AA^{3}, D_{x}=1.667 \mathrm{~g} \mathrm{~cm}^{-3}, 2748$ unique data $\left(2 \theta_{\max }=54.964^{\circ}\right), R$ $=0.0210$ [for 2081 reflections with $I>3.0 \sigma(I)$ ]; $R w=0.0229$ (all data), $S=1.1486$.

\section{Crystallographic Data for Compound ( \pm )-18}

$\mathrm{C}_{12} \mathrm{H}_{15} \mathrm{BrO}_{6}, M=335.15, T=200 \mathrm{~K}$, monoclinic, space group $P 2{ }_{1} / n, Z=4, a=10.1988(2)$, $b=12.0279(1), c=11.1588(2) \AA ; \beta=104.8739{ }^{\circ} ; V=1322.99(4) \AA^{3}, D_{x}=1.683 \mathrm{~g} \mathrm{~cm}^{-3}$, 3027 unique data $\left(2 \theta_{\max }=54.964^{\circ}\right), R=0.0204$ [for 2513 reflections with $I>3.0 \sigma(I)$ ]; $R w=$ 0.0204 (all data), $S=1.1210$.

\section{Structure Determination}

Images for compounds $( \pm)-\mathbf{5},( \pm)-\mathbf{8},( \pm)-\mathbf{1 1},( \pm)-\mathbf{1 4},(-)-15$ and $( \pm)-\mathbf{1 8}$ were measured on a Nonius Kappa CCD diffractometer (MoK $\alpha$, graphite monochromator, $\lambda=0.71073 \AA$ ) while the data for compounds $( \pm)-\mathbf{7}$ and $( \pm)$-15 were measured on a Rigaku SuperNova diffractometer (using $\mathrm{CuK} \alpha$, graphite monochromator, $\lambda=1.54184 \AA$ ) and those for compound $( \pm)$-10 were measured on a Rigaku xCalibur diffractometer (MoK $\alpha$, graphite monochromator, $\lambda=0.71073 \AA$ ). For the first group of compounds, data was extracted using the DENZO package, ${ }^{15}$ while structure solutions was by direct methods (SIR92) ${ }^{16}$ and the structures of all these compounds were refined using the CRYSTALS program package. ${ }^{17}$ In the cases of compounds $( \pm)-\mathbf{7},( \pm)-\mathbf{1 0}$ and $( \pm)-\mathbf{1 5}$ data collection, cell refinement and data reduction employed the CrysAlis PRO program ${ }^{18}$ while SHELXT ${ }^{19}$ and SHELXL ${ }^{20}$ were used for structure solution and refinement. Atomic coordinates, bond lengths and angles, and displacement parameters have been deposited at the Cambridge Crystallographic Data Centre (CCDC no. 1956893-1956900 and 1957119). These data can be obtained free-of-charge via www.ccdc.cam.ac.uk/data_request/cif, by emailing data_request@ccdc.cam.ac.uk, or by contacting The Cambridge Crystallographic Data Centre, 12 Union Road, Cambridge CB2 1EZ, UK; fax: +44 1223336033.

\section{AUTHOR INFORMATION}

\section{Corresponding Author}

*Tel: +61-2-6125-8202. Fax: +61-2-6125-8114. E-mail: Martin.Banwell@anu.edu.au

\section{ORCID}

Martin G. Banwell: 0000-0002-0582-475X

Jiri Mikusek: 0000-0001-5425-0193

\section{Author Contributions}


The manuscript was written through contributions from all of the authors. All of the authors have given approval to the final version of the manuscript.

\section{Notes}

The authors declare no competing financial interest.

\section{ASSOCIATED CONTENT}

\section{Supporting Information}

The Supporting Information is available free-of-charge on the ACS Publications website at DOI: 10.1021/acs.joc.XXXXXX.

${ }^{1} \mathrm{H}$ and ${ }^{13} \mathrm{C}\left\{{ }^{1} \mathrm{H}\right\}$ NMR Spectra for Compounds 4, $( \pm)-5,( \pm)-7,( \pm)-8,( \pm)-10,( \pm)-11,( \pm)-12$, $( \pm)-14,( \pm)-15,( \pm)-2,(-)-18$ and $(+)-19$, HPLC traces used in determining key enantiomeric excesses and plots derived from X-ray analyses (PDF)

X-ray crystallographic data for compound ( \pm )-5 (CIF)

X-ray crystallographic data for compound ( \pm )-7 (CIF)

X-ray crystallographic data for compound ( \pm )-8 (CIF)

X-ray crystallographic data for compound ( \pm )-10 (CIF)

X-ray crystallographic data for compound ( \pm )-11 (CIF)

X-ray crystallographic data for compound ( \pm )-14 (CIF)

X-ray crystallographic data for compound ( \pm )-15 (CIF)

X-ray crystallographic data for compound (-)-15 (CIF)

X-ray crystallographic data for compound ( \pm )-18 (CIF)

\section{ACKNOWLEDGMENTS}

The authors thank the Australian Research Council and the Institute of Advanced Studies at the Australian National University for financial support.

\section{REFERENCES}

1. (a) Pan, P.; Ye, S.; Banwell, M. G. The Application of Dioxygenase-Based Chemoenzymatic Processes to the Total Synthesis of Natural Products. Chem. Asian J. 2019, DOI: 10.1002/asia.201900988. (b) Taher, E. S.; Banwell, M. G.; Buckler, J. N.; Yan, Q.; Lan, P. The Exploitation of Enzymatically-Derived cis-1,2-Dihydrocatechols and Related Compounds in the Synthesis of Biologically Active Natural Products. Chem. Rec. 2018, 18, 239-264 and references cited therein; (c) Tang, F.; Lan, P.; Bolte, B.; Banwell, M. G.; Ward, J. S.; Willis, A. C. Total Synthesis of (+)-Viridianol, A Marine-derived Sesquiterpene 
Embodying the Decahydro-cyclobuta[d]indene Framework. J. Org. Chem. 2018, 83, 1404914056; (d) Dlugosch, M.; Ma, X.; Yang, S.; Banwell, M. G.; Ma, C.; Ward, J. S.; Carr, P. Syntheses of Structurally and Stereochemically Varied Forms of $\mathrm{C}_{7} \mathrm{~N}$ Aminocyclitol Derivatives from Enzymatically-derived and Homochiral cis-1,2-Dihydrocatechols. Org. Lett. 2018, 20, 7225-7228. (e) Bolte, B.; Tang, F.; Lan, P.; Willis, A. C.; Banwell, M. G. Synthetic Studies on the Marine-Derived Sesquiterpene (+)-Viridianol: Divergent Behaviour of Two Structurally Related Ring-Fused Cyclopropanes Under the Same Hydrogenolytic Conditions. Aust. J. Chem. 2019, 72, 305-310.

2. For a point-of-entry into the recent literature on the efforts of other groups in this area see: Borra, S.; Kumar, M.; McNulty, J.; Baidilov, D.; Hudlicky, T. Chemoenzymatic Synthesis of the Antifungal Compound (-)-Pestynol by a Convergent, Sonogashira Construction of the Central Yne-Diene. Eur. J. Org. Chem. 2019, 1, 77-79.

3. For an historical introduction to this topic see: Cerefice, S. A.; Fields, E. K. Formation and Reactions of Dihydrophthalic Acids. J. Org. Chem. 1974, 39, 971-976.

4. $\quad$ For studies on the synthesis and exploitation of such dienes see (a) Breslow, R.; Napierski, J.; Schmidt, A. H. Unsymmetrical Substituent Effects on the Antiaromatic Transition State for the Rearrangement of Bicyclo[2.2.0]hexadiene to Benzene. J. Am. Chem. Soc. 1972, 94, 5906-5907; (b) Bandara, B. M.R.; Birch, A. J.; Raverty, W. D. Organometallic Compounds in Organic Synthesis. Part 13. Stereoselectvity of Complexation of Cyclohexadiene Esters. $J$. Chem. Soc. Perkin Trans. 1, 1982, 1755-1762; (c) Ohno, T.; Ozaki, M.; Inagaki, A.; Hirashima, T.; Nishiguchi, L. Synthesis of 1,2-Disubstituted Benzenes and Biphenyls from Phthalic Acids Through Electroreduction Followed by Electrocyclic Reaction with Alkynes. Tetrahedron Lett. 1993, 34, 2629-2632.

5. Dong, J. L.; Yu, L.-S.-H.; Xie, J.-W. A Simple and Versatile Method for the Formation of Acetals/Ketals Using Trace Conventional Acids. ACS Omega, 2018, 3, 4974-4985.

6. Dong, D. C.; Edward, J. T. Synthesis of Some Brominated Cage Molecules as Possible Precursors to Pentaprismane. J. Chem. Eng. Data 1982, 27, 211-213.

7. $\quad$ Eaton, P. E.; Hudson, R. A. Cyclopentadienone Ketals. J. Am. Chem. Soc. 1965, 87, 27692771.

8. The corresponding diketone is known, see: Bliese, M.; Tsanaktsidis, J. Dimethyl Cubane-1,4dicarboxylate: A Practical Laboratory Scale Synthesis. Aust. J. Chem. 1997, 50, 189-192 and references cited therein.

9. $\quad$ For related conversions see: (a) Halton, B.; Battiste, M. A.; Rehberg, R.; Deyrup, C. L.; Brennan, M. E. Decarbonylation Studies in the endo- and exo-Tricyclo[3.2.1.0 ${ }^{2,4}$ ]octenone 
Series. Stereoelectronic Requirements for Cyclopropyl Participation. J. Am. Chem. Soc. 1967, 89, 5964-5965; (b) Birney, D. M.; Berson, J. A. Synthesis of the Covalent benzene-Carbon Monoxide Cycloadduct, Norborna-2,5-dienon-7-one. Correlation of Kinetic and Thermodynamic Stabilities in Cycloreversion Reactions. Tetrahedron 1986, 42, 1561-1570; (c) Gravett, E. C.; Howard, J. A. K.; Mackenzie, K.; Shi-Xiong, L.; Karadakov, P. B. Sequential Cycloaddition-Cycloreversion-Cycloaddition-Cope Rerrangeemnt with an Annulated Norbornadiene and Electrophilic Dienes. Unusual $\left[\pi_{\mathrm{s}}+\pi_{\mathrm{a}}+\sigma_{\mathrm{a}}\right]$ Transformation of a Pentacyclo[11.4.0.1 $1^{17,10} \cdot 0^{4,13} \cdot 0^{6,11}$ octadeca-3,8,14,17-tetraene. Tetrahedron, 1993, 49, 4699-4710; (d) Knölker, H-J.; Baum, E.; Heber, J. Transition Metal-Diene Complexes in Organic Synthesis, Part 25. Cycloadditions of Annulated 2,5-Bis(trimethylsilyl)cyclopentadienones. Tetrahedron Lett. 1995, 36, 7647-7650; (e) Harmarta, M.; Barnes, C. L.; Brackley, J.; Bohnert, G.; Kirchhoefer, P.; Kürti, L.; Rashatasakhon, P. Generation of Cyclopentadienones from 2-Bromocyclopentenones. J. Org. Chem. 2001, 66, 5232-5236.

10. For a useful point-of-entry into the literature on this topic see: de María, P. D.; GarcíaBurgos, C. A.; Bargeman, G.; van Gemert, R. W. Pig Liver Esterase (PLE) as Biocatalyst in Organic Synthesis: From Nature to Cloning and to Practical Applications. Synthesis 2007, 10, $1439-1452$

11. (a) Bolm, C.; Gerlach, A.; Dinter, C. L. Simple and Enantioselective Nonenzymatic Ring Opening of Cyclic Prochiral Anhydrides. Synlett. 1999, 2, 95-196; (b) Bolm, C.; Schiffers, I.; Dinter, C. L.; Gerlach, A. Practical and Highly Enantioselective Ring Opening of Cyclic Meso-Anhydrides Mediated by Cinchona Alkaloids. J. Org. Chem. 2000, 65, 6984-6991.

12. For a review on this topic see: Díaz de Villegas, M. D.; Gálvez, J. A.; Etayo, P.; Badorrey, R.; López-Ram-de Víu, P. Recent Advances in Enantioselective Organo- catalyzed Anhydride Desymmetrization and its Applications to the Synthesis of valuable Enantiopure Compounds. Chem. Soc. Rev. 2011, 40, 5564-5587.

13. Still, W. C.; Kahn, M.; Mitra, A. Rapid Chromatographic Technique for Preparative Separations with Moderate Resolution. J. Org. Chem., 1978, 43, 2923-2925.

14. Pangborn, A. B.; Giardello, M. A.; Grubbs, R. H.; Rosen, R. K.; Timmers, F. J. Safe and Convenient Procedure for Solvent Purification. Organometallics, 1996, 15, 1518-1520.

15. Otwinowski, Z.; Minor, W. Processing of X-ray Diffraction Data Collected in Oscillation Mode. In Methods in Enzymology, Volume 276: Macromolecular Crystallography, Part A; C. W. Carter Jr. and R. M. Sweet, Eds.; Academic Press: New York, 1997; pp. 307-326. 
16. Altomare, A.; Cascarano, G.; Giacovazzo, C.; Guagliardi, A.; Burla, M. C.; Polidori, G.; Camalli, M. SIR92 - A Program for Automatic Solution of Crystal Structures by Direct Methods. J. Appl. Crystallogr. 1994, 27, 435.

17. Betteridge, P. W.; Carruthers, J. R.; Cooper, R. I.; Prout, K.; Watkin, D. J. Crystals Version 12: Software for Guided Crystal Structure Analysis. J. Appl. Crystallogr. 2003, 36, 1487.

18. CrysAlis PRO Version 1.171.37.35h (release 09-02-2015 CrysAlis171.NET) (compiled Feb 9 2015,16:26:32) Agilent Technologies: Oxfordshire, UK.

19. Sheldrick, G. M. SHELXT - Integrated Space-Group and Crystal-Structure Determination. Acta Cryst. 2015, A71, 3-8.

20. Sheldrick, G. M. Crystal Structure Refinement with SHELXL. Acta Cryst. 2015, C71, 3-8. 